\title{
Subject/object processing asymmetries in Korean relative clauses: Evidence from ERP data
}

\section{Citation}

Kwon, Nayoung, Robert Kluender, Marta Kutas, and Maria Polinsky. 2013. Subject/object processing asymmetries in Korean relative clauses: Evidence from ERP data. Language 89(3): 537-585.

\section{Published Version}

doi:10.1353/Lan.2013.0044

\section{Permanent link}

http://nrs.harvard.edu/urn-3:HUL.InstRepos:11857810

\section{Terms of Use}

This article was downloaded from Harvard University's DASH repository, and is made available under the terms and conditions applicable to Other Posted Material, as set forth at http:// nrs.harvard.edu/urn-3:HUL.InstRepos:dash.current.terms-of-use\#LAA

\section{Share Your Story}

The Harvard community has made this article openly available.

Please share how this access benefits you. Submit a story.

\section{Accessibility}




\section{PROJECT MUSE}

\section{Subject/object processing asymmetries in Korean relative clauses: Evidence from ERP data}

Nayoung Kwon, Robert Kluender, Marta Kutas, Maria Polinsky

Language, Volume 89, Number 3, September 2013, pp. 537-585 (Article)

Published by Linguistic Society of America

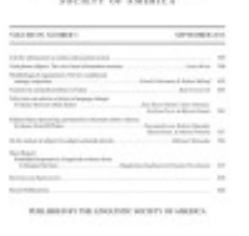

$\Rightarrow$ For additional information about this article

http://muse.jhu.edu/journals/lan/summary/v089/89.3.kwon.html 


\title{
SUBJECT/OBJECT PROCESSING ASYMMETRIES IN KOREAN RELATIVE CLAUSES: EVIDENCE FROM ERP DATA
}

\section{NAYOUNG KwON}

Konkuk University

Marta Kutas

University of California, San Diego

\author{
ROBERT KLUENDER \\ University of California, San Diego \\ MARIA POLINSKY \\ Harvard University
}

\begin{abstract}
Subject relative (SR) clauses have a reliable processing advantage in VO languages like English in which relative clauses (RCs) follow the head noun. The question is whether this is also routinely true in OV languages like Japanese and Korean, in which RCs precede the head noun. We conducted an event-related brain potential (ERP) study of Korean RCs to test whether the SR advantage manifests in brain responses, and to tease apart the typological factors that might contribute to these responses. Our results suggest that brain responses to RCs are remarkably similar in $\mathrm{VO}$ and $\mathrm{OV}$ languages. Our results also suggest that the marking of the right edge of the RC in Chinese (Yang et al. 2010) and Korean and the absence of such marking in Japanese (Ueno \& Garnsey 2008) affect the response to the following head noun. The consistent SR advantage found in ERP studies lends further support to a universal subject preference in the processing of relative clauses.*

Keywords: Korean, relative clauses, ERP, subject/object processing asymmetry, linguistic typology
\end{abstract}

1. Introduction. At least since the pioneering work of Sir William Jones on Sanskrit at the end of the eighteenth century (in which he showed by means of comparisons with Latin and Greek that these languages were related), linguistic analysis has aimed at differentiating those aspects of the human language faculty that are universal in nature, that is, shared by all known languages, from those that are specific to individual (groups of) languages. There has thus always been an inherent tension between emphasizing language-universal vs. language-specific properties in linguistic theorizing.

In recent years, it has become apparent from the results especially of neurophysiological studies that language-universal vs. language-specific aspects of language processing in the brain need to be differentiated in like manner, with a view to determining whether either predominates in a given language. Even though it deals specifically with the processing of relative clauses in Korean, the current study can be viewed as a contribution to this larger area of inquiry.

Both formal and functional approaches to the study of crosslinguistic variation have suggested that processing may play a role in shaping grammars. Various proposals in the formal tradition have equated rules of the grammar with computational operations of the parser (Miller \& Chomsky 1963, Fodor et al. 1974, Bresnan \& Kaplan 1982, Berwick \& Weinberg 1983), while functionalists have also suggested that languages are structured in the ways they are because of processing constraints (Keenan \& Comrie 1977, Hawkins 1990). We frame our discussion in these terms to highlight the fact that universal and specific properties of language can be identified and compared not only in terms of language structure, but also in terms of language processing.

* This research was supported by a research grant from the Department of Linguistics at the University of California, San Diego, and NRF2013-A003-0011 to Nayoung Kwon and by NICHD22614 to Marta Kutas. We thank Soonja Choi, Victor Ferreira, Susan Garnsey, Grant Goodall, John Hale, Edson Miyamoto, Roger Levy, William O'Grady, Mieko Ueno, and Shravan Vasishth for helpful discussion and comments. We also thank anonymous referees for their constructive comments and suggestions. 
In the following sections, we review a number of typological properties hypothesized to affect the processing of relative clauses crosslinguistically. We first address more general structural properties in $\S 1.1$, including the apparent processing advantage of subject relative clauses, in light of (i) the processing difficulty associated with prenominal relative clauses, (ii) the processing differences between filler-gap vs. gap-filler dependencies in relative clauses, and (iii) the effect of dropped arguments on relative clause processing. We then address structural properties of the major East Asian languages (Chinese, Japanese, and Korean) and their parametric variation with respect to: (i) headedness, (ii) marking of noun phrases for case, and (iii) marking of a prenominal relative clause at its right edge (\$1.2). We review two main types of theoretical explanation for the subject relative processing advantage in $\S 1.3$, and then discuss previous ERP results relevant to the processing of relative clauses in $\S 1.4 .{ }^{1}$ We next turn to our study $(\S 2)$, first providing predictions based on this background, and then outlining our experimental details and presenting the results. Finally, we discuss the experimental results in light of language-universal vs. language-specific aspects of language processing in consideration of structural properties of Korean ( $\$ 3)$, and provide some concluding thoughts.

1.1. The typology of Relative Clauses and CONSEQuences FOR PROCESSING. Subject relative clauses (SRs; example 1a in Table 1) are more common across the world's languages than object relative clauses (ORs; $1 \mathrm{~b}$ in Table 1) and other relative clause (RC) types (Keenan \& Comrie 1977). ${ }^{2}$

This is true regardless of whether a relative clause is postnominal, that is, follows its head noun ('reporter'), as it does in English and related languages (1 in Table 1), or prenominal, that is, precedes its head noun, as is the case in many other languages including Chinese, Japanese, and Korean, schematically represented with English lexical items in 2 of Table 1.

Keenan and Comrie's claim that this pattern holds because subject relatives are inherently easier to process has been substantiated in numerous studies across languages using a wide variety of psycholinguistic measures in English (self-paced reading time: King \& Just 1991; ERP: King \& Kutas 1995; PET: Stromswold et al. 1996, Caplan et al. 1998, 1999, Caplan et al. 2000; fMRI: Just et al. 1996, Caplan et al. 2002, Cooke et al. 2002, Constable et al. 2004, Chen et al. 2006, Caplan et al. 2008; eye-tracking: Traxler et al. 2002), in Dutch (Frazier 1987), in German (Mecklinger et al. 1995, Schriefers et al. 1995, Münte et al. 1997, Bader \& Meng 1999, Schwartz 2007), in French (Frauenfelder et al. 1980, Holmes \& O’Regan 1981, Cohen \& Mehler 1996), in Hebrew (Friedmann \& Novogrodsky 2004, Arnon 2005), in Turkish (Kahraman et al. 2010), and in Russian (Polinsky 2011).

It has also been claimed in the typological literature that the choice of relative clause placement, viz. pre- or postnominal, is influenced by processing efficiency. Languages in general tend to be consistent as to whether the head of a phrase occurs at its beginning or at its end (Greenberg 1963), and can be divided into V[erb]O[bject] and $\mathrm{O}[\mathrm{bject}] \mathrm{V}[\mathrm{erb}]$ types (Dryer 1992). ${ }^{3}$ In VO languages like English, verbs and preposi-

\footnotetext{
${ }^{1}$ Readers may wish to skim or skip over sections devoted to concepts with which they are familiar, but are encouraged to pay attention to sections with which they may be less familiar. The extensive background we provide will be crucial to the interpretation of our results, since Korean is relatively understudied with respect to its processing parameters, which in turn reflect its typological properties.

${ }^{2}$ For details of Keenan and Comrie's proposal, see $\$ 1.3$.

${ }^{3}$ VO languages can be head-initial or verb-medial, but not head-final, while OV languages are always head-final; in what follows we thus use the labels OV and head-final interchangeably.
} 
(1) ENGLISH

a. Postnominal SUbJect Relative CLAUSE With FILLER-GAP ORDERING The reporter ${ }_{i}[\mathrm{RC}$ who $\ldots i$ attacked the senator $]$ admitted the error. FILLER $\longleftrightarrow$ GAP

b. Postnominal obJect Relative ClaUSe With FILLER-GAP ORDERING The reporter ${ }_{i}\left[\mathrm{RC}\right.$ who the senator attacked _ $\left.{ }_{i}\right]$ admitted the error. FILLER $\longleftrightarrow$ GAP

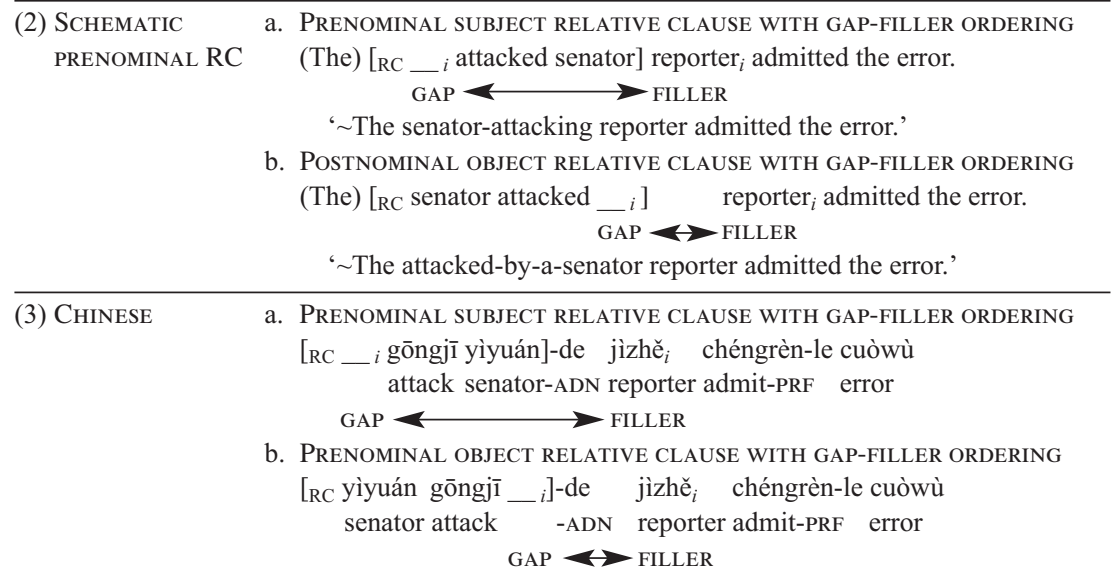

(4) JAPANESE

a. Prenominal SubJect Relative Clause With GAP-FILLER ORDERING [RC_ ${ }_{i}$ giin-ga hinanshita] $\mathrm{kisha}_{i}$-ga ayamari-o mitometa senator-ACC attacked reporter-NOM error-ACC admitted $\mathrm{GAP} \longleftrightarrow$ FILLER

b. Prenominal obJect Relative ClaUSE With GAP-FILLER ORDERING [RC giin-ga _ ${ }_{i}$ hinanshita] kisha $_{i}$-ga ayamari-o mitometa senator-NOM attacked reporter-NOM error-ACC admitted GAP $\longleftrightarrow$ FILLER

(5) KOREAN

a. Prenominal SubJect Relative ClaUSE With GaP-Filler ORDERING [RC _ ${ }_{i}$ uywon-ul kongkyekha-n] kica $_{i}$-ka silswu-lul siinhayssta senator-ACC attack-ADN reporter-NOM error-ACC admitted GAP $\longleftrightarrow$ FILLER

b. Prenominal obJect Relative Clause With GaP-Filler ORDERING

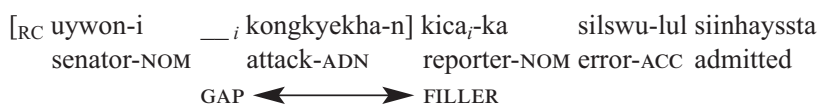

TABLE 1. Subject vs. object relatives in English, Chinese, Japanese, and Korean.

tions precede their objects, whereas in OV languages like Korean, verbs and prepositions (actually 'postpositions') follow their objects. The situation with relative clauses is not as straightforward. On the one hand, 98\% of head-initial languages (Dryer 1992) have head-initial (i.e. postnominal) relative clauses ( 1 in Table 1), consistent with the fact that they also have head-initial VO word order and prepositions. On the other hand, less than half of head-final languages $(41 \%)$ with OV word order and postpositions also have head-final (i.e. prenominal) relative clauses (2 in Table 1) (Dryer 1992). The other 59\% have head-initial (i.e. postnominal) relative clauses instead, as in English (see also Hawkins 1983, Lehmann 1984). Overall, this leads to a higher percentage of postnominal/head-initial relative clauses crosslinguistically. The underrepresentation of prenominal/head-final relative clauses across the world's languages has been attributed to the fact that, given left-to-right sentence processing, prenominal/head-final relative clauses 
invite temporary misanalysis (Hawkins 1990, 1999, 2004; see also Fodor 1983). ${ }^{4}$ If the beginning of a relative clause is not marked as such, a sentence-initial relative clause like those in 2 in Table 1 can easily be misinterpreted as the main clause of the sentence. ${ }^{5}$ This misanalysis necessitates complex and costly revision processes later in the sentence when additional structural cues indicate that the sentence-initial string was in fact a relative clause (e.g. at the head noun 'reporter' in 2 of Table 1). The claim is that such structures are avoided crosslinguistically in order to minimize the burden of reanalysis.

The proper interpretation of any type of relative clause, either pre- (2 in Table 1) or postnominal (1 in Table 1), additionally requires the mutual dependency of the head noun, which we refer to as the 'filler', and its 'gap' in the relative clause (i.e. the position where it would ordinarily occur in a declarative clause, indicated as ' 1978). The filler must be interpreted at the gap position in order to determine its thematic role (i.e. whether it is the agent, patient, recipient, etc. of the action expressed by the relative clause verb) and grammatical function (i.e. whether it is the subject, object, indirect object, etc. of the relative clause), and the gap position receives its referential identity from the filler.

Thus pre- and postnominal relatives also differ with respect to the relative ordering of the head noun filler ('reporter') and its gap: in postnominal/head-initial relatives ( 1 in Table 1), the filler precedes the gap, thus creating 'forward' filler-gap ordering, while in prenominal/head-final relatives ( 2 in Table 1$)$, the filler follows the gap, creating 'backward' gap-filler ordering. Each ordering presents its own processing challenges. A forward filler-gap dependency in a postnominal/head-initial relative clause (1 in Table 1) requires the encoding of the head noun 'reporter' in working memory and its retrieval at the gap position for thematic role assignment (i.e. as agent of the 'attacking' event). As outlined in $\S 1.3$, this ordering has been shown to incur a number of processing costs. By contrast, a backward gap-filler dependency in a prenominal/head-final relative clause ( 2 in Table 1) may require the encoding of an unfilled gap (i.e. either the unspecified agent of the verb attack, as in $X$ attacked the senator, or the argument and/or phrase structure representation of the entire relative clause) in working memory, and its subsequent retrieval at the head noun position, for establishing the referent of the previously unspecified participant in the relative clause (i.e. who or what was it that did the attacking?). The difference in processing costs between these types of memory operations and those involved in a forward filler-gap dependency is still an open question.

Moreover, there is a further crosslinguistic difference that affects the processing of gap-filler ordering. On the one hand, sentence-initial relative clauses like 2 in Table 1 whose left edge is not marked in any way can, as pointed out above, initially be misinterpreted as a main clause under certain circumstances. On the other hand, one might expect from English that a gap-filler dependency like 2a in Table 1 would have a major impact on processing routines precisely because there is a missing argument in the initial clause. In other words, it might seem obvious that this is a relative clause structure because of the missing argument. The problem with this assumption is that the dropping of arguments is very common in languages like Chinese, Japanese, and Korean. In the case of Korean, subjects in spoken language are dropped $69.4 \%$ of the time, and objects

\footnotetext{
${ }^{4}$ For expository purposes we present a simplified version of Hawkins's proposal; for the full proposal, see Hawkins 1990.

${ }^{5}$ This misanalysis as a main rather than a relative clause has been attributed to the MINIMAL ATTACHMENT parsing heuristic, in which the parser by default assumes the simplest structure possible (Frazier 1985, Hawkins 1990).
} 
$52.8 \%$ (Kim 2000). Thus, encountering a missing argument is not necessarily an indication that one is processing a relative clause.

In summary, subject relative clauses are more common across the world's languages, and have been shown to be easier for language users to process in VO languages. In this study we investigate whether this is true of OV languages (e.g. Korean) as well. Languages tend to be consistent in their headedness properties, as observed in head-initial languages, of which virtually all those surveyed likewise have head-initial relative clauses. Consistency of headedness does not, however, seem to hold in the ordering of relative clauses in head-final languages, of which many exhibit head-initial relative clauses instead, by hypothesis to avoid misanalysis of a sentence-initial relative clause as the main clause. The difference in processing costs incurred by filler-gap ordering in head-initial relative clauses vs. gap-filler ordering in head-final relative clauses, particularly in the presence of widespread argument drop, is another focus of our study.

We show that, despite (i) the consistent head-final nature of Korean, (ii) the consequent gap-filler ordering of its relative clauses, and (iii) the widespread occurrence of argument drop, especially of subjects, subject relatives still appear easier to process in Korean, consistent with Keenan and Comrie's (1977) original claim. Furthermore, brain responses to relative clauses turn out to be remarkably similar in English and Korean, which we claim is evidence for language-universal processing. However, the differences in brain response to subject vs. object relative clauses are localized to different sentence positions in English and Korean, a language-particular processing effect tied to specific typological properties of the individual languages in question.

1.2. Prenominal relative Clauses across east asian languages: Structure AND PROCESSING. Subject relative clauses have been found to be more easily processed in languages with postnominal relative clauses. For prenominal relative clauses, this same subject relative preference has been consistently replicated in Japanese (selfpaced reading time: Kanno \& Nakamura 2001, Miyamoto \& Nakamura 2003, Ishizuka et al. 2003; ERP: Ueno \& Garnsey 2008) ${ }^{6}$ and in Korean (self-paced reading time: Kwon et al. 2006, Kwon 2008b; eye-tracking: Kwon et al. 2010). Studies of Mandarin, by contrast, have produced far less straightforward results, with some studies finding a subject relative processing advantage, just as in English and Japanese (self-paced reading time: Lin \& Bever 2006, Chen et al. 2010), while others have found an object relative processing advantage (self-paced reading time: Hsiao \& Gibson 2003, Lin \& Garnsey 2007, Chen et al. 2008, Lin 2010, Gibson \& Wu 2013; maze-task: Qiao et al. 2012). For Cantonese, there seems to be a preference for object relatives at least in child language (Yip \& Matthews 2007).

One possible explanation for this is differences in basic word order. Japanese is strictly head-final, with SOV word order, as shown in 4 in Table 1. Chinese, by contrast, exhibits mixed headedness. It is for the most part VO, with SVO word order and prepositions; however, it presents something of an anomaly with respect to its relative clause ordering. Of the sixty-one head-initial languages examined by Dryer (1992), Chinese is

\footnotetext{
${ }^{6}$ Although two studies (Nakamura 2000, Ishizuka et al. 2006) have reported a processing advantage for ORs in Japanese, Nakamura (2000) attributed her result to a garden-path effect associated with SRs (Kanno \& Nakamura 2001). When the experimental sentences were controlled for this garden-path effect, the OR advantage disappeared and an SR advantage emerged (Kanno \& Nakamura 2001). Similarly, the OR processing advantage reported by Ishizuka and colleagues (2006) was not replicated in follow-up studies, and they in fact found an SR processing advantage in their second follow-up experiment (Tomoko Ishizuka and Ted Gibson, p.c.; see also Kwon et al. 2010 for detailed discussion of Ishizuka et al. 2006).
} 
the sole language that does not have postnominal/head-initial relative clauses; it has prenominal/head-final relative clauses instead, as shown in 3 in Table 1.

However, there are further typological differences between Japanese and Chinese relative clauses that might account for why Japanese exhibits a consistent subject relative preference while Chinese does not. On the one hand, a feature that often correlates with strict head-final word order is the overt marking of noun phrases for case: ${ }^{7}$ note from example 4 of Table 1 that Japanese subject noun phrases are marked nominative (NOM) and direct object noun phrases accusative (ACC); there is no equivalent case marking in example 3 of Table 1 for Chinese. On the other hand, Mandarin (but not Cantonese) exhibits a typological feature missing in Japanese, in that it marks the end (right edge) of its relative clauses with a clitic - de attached to the final word of the relative clause. ${ }^{8}$

These three typological features (consistent headedness, case marking, and relative clause marking) could contribute to the difference in relative clause preferences shown by Japanese (subject preference) vs. Chinese (conflicting results) across studies. In this regard, Korean is a good test case, since it exhibits all three of these features ( 5 in Table 1). Like Japanese, it is consistently head-final with SOV word order and prenominal/ head-final relative clauses, and it also marks its noun phrases for case (i.e. subjects with nominative and objects with accusative case). However, similar to Chinese but unlike Japanese, Korean demarcates its relative clauses by attaching a so-called adnominal marker (ADN) to the clause-final verb. ${ }^{9}$ A summary of the three typological features in these languages is given in Table 2.

$\begin{array}{lcccc} & \text { CLAUSAL WORD ORDER } & \text { PRENOMINAL RC } & \text { NPS CASE MARKED } & \text { RC EDGE MARKED } \\ \text { JAPANESE } & \text { head-final: SOV } & \text { yes } & \text { yes } & \text { no } \\ \text { KOREAN } & \text { head-final: SOV } & \text { yes } & \text { yes } & \text { yes } \\ \text { CHINESE } & \text { head-initial: SVO } & \text { yes } & \text { no } & \text { yes }\end{array}$

TABLE 2. Typological features of interest in Japanese, Korean, and Chinese.

To the extent that Korean patterns with Japanese in terms of its relative clause preferences and brain responses, this would confirm that the difference in the Japanese vs. Chinese results is attributable to parametric differences in the consistency of headedness and/or case marking. But to the extent that Korean patterns with Chinese, this would indicate that marking the right edge of a head-final relative clause constitutes a crucial typological factor. As a first step toward addressing these questions, we utilize an on-line measure that can provide both quantitative and qualitative information about the time course of relative clause processing in Korean, namely ERP methodology.

We show that brain responses at the head noun position in Korean are more similar to those in Chinese (Yang et al. 2010) than to those in Japanese (Ueno \& Garnsey 2008). We attribute this to the fact that both Korean and Chinese place overt morphological

\footnotetext{
${ }^{7}$ Among numerous SOV languages, only Abkhaz (Hewitt 1979) seems to be a language without such overt case marking. A large proportion of SVO languages, by contrast, exhibit no case marking (Mallinson \& Blake 1981:101).

${ }^{8}$ This clitic is glossed as ADN for ease of exposition in Table 1, but it is more accurately used for various kinds of subordination and modification relationships within noun phrases in Chinese: adjectives, possessives, nominal and clausal complements, and relative clauses. At any rate, in 3 of Table 1, the clitic clearly marks the end of a relative clause preceding the head noun, the main clause subject 'reporter'.

${ }^{9}$ The adnominal marker - $(n u) n$ attached to the embedded verb is technically not a relative clause marker in Korean, either, as it also marks the complement clauses of abstract head nouns, as in [The fact [that the reporter attacked the senator]] surprised the press corps. See $\S 2$ for detailed discussion.
} 
markers at the right edge of the relative clause. At the same time, the consistent preference for subject relatives in Korean and Japanese but not Chinese suggests that consistency of headedness parameters, and possibly also the use of overt case marking, is responsible for this crosslinguistic difference in consistency of processing preferences. These observations are further discussed in the light of the relationship between morphostructural properties of language and parsing in $\$ 3.5$ below.

1.3. TheORETICAL ACCOUNTS OF THE SUBJECT RELATIVE PROCESSING ADVANTAGE. For ease of exposition, we group a variety of theoretical accounts of the subject relative processing advantage into two broad categories of explanation: those that deal with surfacelevel features such as the linear string, and those that refer to abstract levels of phrase structure representation.

In the first category are accounts that define the subject relative processing advantage in terms of activation and subsequent decay of a filler in working-memory stores as intervening material is processed between filler and gap (or its subcategorizer, the relative clause verb 'attacked') in $1 \mathrm{~b}$ of Table 1 . In this approach, processing difficulty increases as a function of filler-gap distance, either in terms of specific types of linguistic units in the linear string (e.g. Gibson 1998, 2000, Warren \& Gibson 2002) or in terms of realtime units (Lewis \& Vasishth 2005, Lewis et al. 2006). As soon as an unassigned filler ('reporter') is detected (at 'who'), a corresponding gap is postulated in both subject (1a of Table 1) and object relative clauses (1b of Table 1). However, filler-gap distance is longer in ORs (1b) than in SRs (1a), as indicated by the arrows. ORs in head-initial languages with forward filler-gap dependencies are therefore predicted and have been found to be more difficult.

In contrast, a gap precedes its filler and there is no relative pronoun to flag it in languages with prenominal relative clauses like Chinese, Japanese, and Korean. Moreover, since arguments are frequently dropped in these languages, the position at which the absence of an argument is detected will differ for subject vs. object relative clauses, rendering predictions based on linear/temporal distance more complex. For example, in Japanese and Korean (examples 4 and 5 respectively in Table 1), with SOV word order, a missing subject will be postulated at the sentence-initial, noncanonical NP-ACC (4a and 5a), while a missing object will be detected at a transitive verb lacking an internal argument ( $4 \mathrm{~b}$ and $5 \mathrm{~b}$ ). In Chinese, with its basic SVO word order (example 3 in Table 1), absence of a subject will first be detected at the sentence-initial verb (3a), while a missing object will be postulated at the clitic - de following the verb ( $3 \mathrm{~b}$; see n. 8). Consequently, if linear/temporal distance is calculated with respect to the point at which a missing argument is detected, SRs should be more difficult to process than ORs due to their longer linear/temporal distance in all of the East Asian languages, as indicated by the arrows in Table 1.

Processing models based on linear/temporal distance therefore predict a processing advantage for SRs in forward filler-gap dependencies in languages like English and an OR processing advantage in backward gap-filler dependencies in languages like Chinese, Japanese, and Korean. ${ }^{10}$ This prediction is consistent with studies of Chinese that report an OR processing advantage (Hsiao \& Gibson 2003, Lin \& Garnsey 2007, Chen et al. 2008, Qiao et al. 2012, Gibson \& Wu 2013), but not with the reported SR processing advantage in Japanese and Korean (Kanno \& Nakamura 2001, Ishizuka et al. 2003, Miyamoto \& Nakamura 2003, Kwon 2008b, Ueno \& Garnsey 2008, Kwon et al.

\footnotetext{
${ }^{10}$ For detailed discussion of accounts based on gap postulation and reactivation of missing argument slots, please refer to Kwon et al. 2010 and Gibson \& Wu 2013.
} 
2010) or with other studies of Chinese that report an SR processing advantage (Lin \& Bever 2006, Chen et al. 2010).

In the second category of theoretical approaches are those that account for the SR/OR processing asymmetry in terms of more abstract levels of representation, namely grammatical relations (Keenan \& Comrie 1977) or phrase structure (O’Grady 1997). Keenan and Comrie's (1977) ACCESSIBILITY HIERARCHY (1) was originally proposed as a universal constraint on relative clause formation: if a language allows relativization on one grammatical position in this ordering, then it must also allow relativization on all grammatical positions to the left of that position on the scale shown in 1 .

(1) Accessibility hierarchy: subject $>$ direct object $>$ indirect object $>$ oblique $>$ genitive $>$ object of comparison

(Keenan \& Comrie 1977:66) This is also argued to directly reflect 'psychological ease of comprehension' (Keenan \& Comrie 1977:88). In other words, a grammatical role higher on the accessibility hierarchy is argued to be easier to process and therefore more common crosslinguistically (see also Hawkins 1999, 2004).

O'Grady's (1997) PHRASE-STRUCTURAL DISTANCE HYPOTHESIS (2) accounts for the processing advantage of SRs in terms of the phrase-structural distance between a gap and its filler.

(2) A structure's complexity increases with the number of XP categories (S, VP, etc.) between a gap and the element with which it is associated.

(O’Grady 1997:136)

As shown in Figure 1, ORs exhibit greater phrase-structural distance between gap and filler than SRs (three XPs vs. two XPs), and this relatively greater distance is assumed to translate into a processing disadvantage (cf. O’Grady 2011).

a. $\mathrm{SRs}$

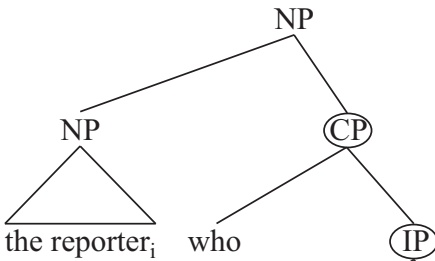

b. ORs

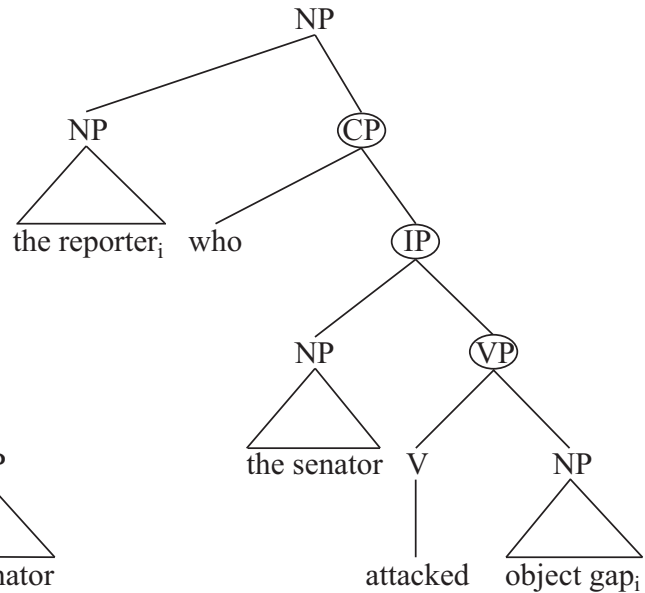

FIGURE 1. Phrase structure of subject (SR) and object (OR) relatives.

This second class of models therefore predicts a consistent processing advantage for SRs in both forward and backward filler-gap dependencies. This prediction is consistent with the SR processing advantage found in forward filler-gap dependencies in English and backward gap-filler dependencies in Japanese, Korean, and some studies of Chinese - but not with the OR processing advantage reported in other studies of Chi- 
nese (Hsiao \& Gibson 2003, Lin \& Garnsey 2007, Chen et al. 2008, Qiao et al. 2012, Gibson \& Wu 2013).

In sum, models based on linear/temporal distance predict that SRs will be more difficult to process in Korean, while models based on grammatical relations and/or phrase structure representations predict that ORs will be more difficult.

1.4. Previous erp studies of Filler-Gap DePendencies. Thus far we have discussed filler-gap dependencies only in relative clauses, as in 3. However, filler-gap dependencies are also found in other constructions such as wH-questions (4) and scrambling constructions in German, Japanese, and Korean (5).

(3) $\left[\mathrm{RC}_{\mathrm{RC}}\right.$ The reporter $_{i}$ [who the senator attacked _ $\left.{ }_{i}\right]$ ] admitted the error.

(4) Which reporter ${ }_{i}$ did the senator attack ${ }_{i}$ ?

(5) reporter $_{i}$-ACC senator-NOM _ ${ }_{i}$ attacked

'The senator attacked the reporter.'

Forward filler-gap dependencies with object fillers like these consistently cause additional processing difficulty, as indexed by (i) slow anterior negative brain potentials initiated at the onset of a dependency (frequently persisting up to or even beyond the gap position), and (ii) transient left anterior negativity and/or P600 responses around gap positions (relative clauses: King \& Kutas 1995, Müller et al. 1997, Münte et al. 1997, Weckerly \& Kutas 1999, Vos et al. 2001; WH-questions: Kluender \& Kutas 1993a,b, Kluender \& Münte 1998, Kaan et al. 2000, Fiebach et al. 2002, Felser et al. 2003, Phillips et al. 2005, Gouvea et al. 2010; scrambling constructions: Rösler et al. 1998, Matzke et al. 2002, Schlesewsky et al. 2003, Ueno \& Kluender 2003, Hagiwara et al. 2007, Wolff et al. 2008).

Left anterior negativity (LAN) is a negative-going wave with an anterior spatial distribution: that is, it is largest over anterior regions of the scalp, and often but not always left-lateralized (Kluender \& Kutas 1993a,b; see also King \& Kutas 1995, Fiebach et al. 2002, Ueno \& Kluender 2003, Phillips et al. 2005). In terms of its time course, LAN has been observed both in a transient form $300-500$ or 300-600 ms after the onset of a single word, and in a sustained slow potential form that spans several words and may last for several seconds. ${ }^{11}$ Crucial for present purposes, LAN has been found to be related to working memory, a system involved with holding transitory information in mind for further manipulation and processing. For example, Münte, Schiltz, and Kutas (1998) showed that sentences that taxed working memory more heavily elicited sustained negativity over left anterior regions compared to control sentences, and the difference between the two conditions was larger in participants with higher verbal working-memory capacity (see also King \& Kutas 1995 for similar differences between good and poor comprehenders; but see Vos et al. 2001 and Fiebach et al. 2002 for larger differences in participants with lower working-memory capacity).

In this context, slow anterior negative brain potentials to ORs as in 3 have been interpreted as indexing higher working-memory costs for ORs than for SRs (King \& Kutas 1995). For example, in postnominal SRs (example 1a in Table 1), the head noun 'reporter' is immediately assigned a thematic role from the embedded verb, allowing simultaneous identification of the grammatical function of the head noun within the relative clause. In postnominal ORs (example 1b in Table 1), by contrast, the head noun

\footnotetext{
${ }^{11}$ LAN has also been observed in response to morphosyntactic anomalies such as subcategorization and phrase structure violations (Neville et al. 1991, Münte et al. 1993, Rösler et al. 1993), inflection/agreement violations (Kutas \& Hillyard 1983, Münte et al. 1993, Osterhout \& Mobley 1995), and case violations (Coulson et al. 1998).
} 
'reporter' remains without a thematic role or grammatical function until the gap position is reached, which constitutes an additional burden on the working-memory system (Gibson 1990). The slow anterior negativity in response to forward filler-gap dependencies within the relative clause region of ORs is purported to be an index of this cost (King \& Kutas 1995). ${ }^{12}$

Transient LAN responses to the main clause verb position (i.e. immediately following the gap position) in postnominal ORs have instead been taken to index higher processing costs of associating gaps with their fillers. In SRs (1a in Table 1), thematic role assignment by the embedded ('attacked') and main ('admitted') clause verbs occurs at different points in sentence processing (embedded verb: early relative clause region; main verb: immediately after the relative clause region), while in ORs (1b in Table 1), the head noun receives thematic roles from the embedded ('attacked') and main ('admitted') verbs at approximately the same time (embedded verb: at the end of the relative clause region; main verb: immediately after the relative clause region), resulting in a greater number of simultaneous long-distance computational operations in ORs at that position. Greater amplitude transient LAN is taken to be an index of this cost (Kluender \& Kutas 1993a,b, King \& Kutas 1995).

The P600, a late positive-going transient response to a single word, is considered to be a sign of syntactic processing difficulty; onset latency varies, but classic effects occur between about 500 and $800 \mathrm{~ms}$. The P600 has largely been elicited by morphosyntactic anomalies (Neville et al. 1991, Osterhout \& Holcomb 1992, Friederici et al. 1993, Hagoort et al. 1993). Importantly, however, syntactic violations are not a prerequisite for eliciting a P600: P600s have also been elicited preceding the gap positions of forward filler-gap dependencies in wH-questions (Kaan et al. 2000, Fiebach et al. 2002, Felser et al. 2003, Phillips et al. 2005, Gouvea et al. 2010) and in Japanese scrambling contexts (Ueno \& Kluender 2003, Hagiwara et al. 2007), occasionally in combination with transient LAN responses. Kaan and colleagues (2000) argued that the P600 in response to gap positions is an index of syntactic integration (see also Fiebach et al. 2002, Phillips et al. 2005).

Reading-time studies of Japanese (Kanno \& Nakamura 2001, Ishizuka et al. 2003, Miyamoto \& Nakamura 2003) and Korean (Kwon 2008b, Kwon et al. 2010) relative clauses show the same slowed reading times to ORs that have been reported in headinitial languages like English with forward filler-gap dependencies. What remains to be determined is whether the same cognitive/neural mechanisms underlie the subject preference in both forward filler-gap dependencies (relative clauses and wH-questions in English, German, and Dutch, and scrambling in German, Japanese, and Korean) and backward gap-filler dependencies (relative clauses in Japanese and Korean). We also wanted to investigate the extent to which parametric variation across the East Asian languages (§1.2) might affect brain responses.

\footnotetext{
12 The negativity initiated at the onset of the dependency, however, generally does not increase cumulatively across the course of the dependency (King \& Kutas 1995, Phillips et al. 2005, Hagiwara et al. 2007, Ueno \& Kluender 2009). That is, a sustained anterior negativity is sensitive to the presence of a dependency but not to its length. This is consistent not only with models of verbal working memory that do not posit a storage function (e.g. McElree 2001, Lewis \& Vasishth 2005, Lewis et al. 2006), but also with certain studies of visual working memory using fMRI in humans (Jha \& McCarthy 2000) and single-unit recording in monkeys (Zaksas \& Pasternak 2006) that show activation only at encoding and retrieval stages, and no evidence of a maintenance function spanning the two. Figure 5 below of our own data can be interpreted in this same way; see $§ 3.4$.
} 
Thus far there have been two ERP studies of backward gap-filler dependencies in prenominal relative clauses in East Asian languages: Japanese (Ueno \& Garnsey 2008) and Chinese (Yang et al. 2010). ${ }^{13}$ Ueno and Garnsey (2008) observed ERP effects that were remarkably similar to those found in forward filler-gap dependencies: when compared to SRs similar to 4a in Table 1, Japanese ORs similar to $4 \mathrm{~b}$ in Table 1 elicited (bilateral) anterior negativity from the onset of the embedded verb ('attacked'), where it was significant, through the head noun position ('reporter'), where it was marginal. Ueno and Garnsey interpreted this response as indexing higher working-memory demands related to structural distance (O'Grady 1997). Additionally, there was a slow positive-going potential to ORs ( $4 \mathrm{~b}$ in Table 1 ) with a centro-posterior maximum starting $\sim 500 \mathrm{~ms}$ after the head noun ('reporter') and persisting across the rest of the sentence. Although this positivity differed substantially from the standard P600 in its morphology and time course (i.e. it was a sustained rather than a transient effect), Ueno and Garnsey argued that it indexed syntactic integration difficulty in ORs due to the greater phrase-structural complexity of ORs compared to SRs (O'Grady 1997).

The design of the materials in the Yang et al. 2010 ERP study of Chinese relative clauses was different enough that the effects within the relative clause region are not comparable. However, at the head noun position there was again a sustained centralfrontal negativity in response to ORs (3b in Table 1) compared to SRs (3a in Table 1), albeit with no subsequent late positivity.

Based on these previous ERP studies, we can make the predictions found in the next section for brain responses to relative clauses in Korean.

2. EXPERIMENT.

2.1. Predictions. Whether a dependency has filler-gap or gap-filler ordering, a successful parse depends on appropriate and timely association of the two dependent elements. To make predictions about the processing of backward gap-filler dependencies, a reasonable starting point is applying what we know about the processing of forward filler-gap dependencies (6 and 7) to the surface word-order regularities of backward gap-filler dependencies ( 8 and 9 ).

(6) Processes involved in forward filler-gap dependencies

a. A filler (or incomplete dependency) needs to be encoded in working memory in anticipation of a gap.

b. At the gap site, the parser needs to locate an appropriate filler in working memory to associate with the gap.

c. The filler needs to be integrated with the gap.

(7) Neuro/cognitive indices of processing forward dependencies

a. Encoding a filler in working memory elicits a sustained anterior negativity, often (but not always) left-lateralized (King \& Kutas 1995, Fiebach et

\footnotetext{
${ }^{13}$ There is one ERP study of Basque, an ergative, head-final language with prenominal relative clauses (Carreiras et al. 2010). The authors of this study reported an effect of late positivity in response to the disambiguation point of subject vs. object relative clauses that contained a temporary ambiguity; however, the latency (300-500 ms), distribution (left anterior), and morphology of this ERP effect are unusual for a late positivity, raising questions about its polarity. The authors moreover proposed that the OR advantage they report could be accounted for in terms of sensitivity to the absolutive-ergative distinction in Basque (in ergative languages, the absolutive is often a privileged argument for relativization; see Dixon 1994). However, as shown in Polinsky et al. 2012, this result directly follows from frequency effects (see also Clemens et al. 2012). We do not consider the impact of ergativity here, but instead base our predictions on studies of East Asian languages with accusative-nominative alignment that are typologically more comparable to Korean.
} 
al. 2002, Felser et al. 2003, Ueno \& Kluender 2003, Phillips et al. 2005, Hagiwara et al. 2007).

b. The retrieval of a filler to associate with the gap seems to be indexed by a transient, typically left-lateralized anterior negativity (LAN; Kluender \& Kutas 1993a,b, King \& Kutas 1995, Ueno \& Kluender 2003).

c. Filler-gap integration at the gap site has been claimed to be indexed by a late positivity (Kaan et al. 2000, Fiebach et al. 2002, Felser et al. 2003, Ueno \& Kluender 2003, Phillips et al. 2005, Hagiwara et al. 2007).

(8) Hypothesized processes involved in backward gap-filler dependencies

a. A gap (lack of a required argument of the embedded verb) needs to be encoded in working memory to complete the dependency.

b. At the filler site, the parser needs to locate an appropriate gap in working memory to associate with the filler.

c. The gap needs to be integrated with the filler.

(9) Hypothesized neuro/cognitive indices of processing backward dependencies

a. Encoding a gap in working memory might elicit a sustained anterior negativity.

b. The retrieval of a gap from working memory to associate with the filler might elicit transient left-lateralized anterior negativity (LAN).

c. Gap-filler integration at the filler site might be indexed by a late positivity.

On the assumption that such a processing account is on the right track, the question arises of whether each of the analogous processes in forward filler-gap (6) and backward gap-filler dependencies (8) will elicit a similar brain response (9). In processing models based on the linear/temporal distance of an incomplete dependency, we might predict a larger ERP response to SRs than to ORs if encoding a gap in working memory incurs a processing cost, since the linear distance between gap and filler is longer in SRs (5a in Table 1) than in ORs (5b in Table 1).

However, it seems unlikely to us that there would be ERP effects associated with additional working-memory requirements for encoding a gap in working memory in a backward gap-filler dependency as there are for encoding a filler in working memory in English and other West Germanic languages. First, unlike forward filler-gap dependencies, in which a filler reliably signals the presence of a gap (active filler hypothesis: Frazier \& Clifton 1989), in backward gap-filler dependencies in Korean (and likely in Chinese and Japanese as well), a gap does not reliably indicate the presence of a filler. Because Korean liberally drops both subject and object arguments (Kim 2000), when the parser encounters a missing argument in Korean, there is no reason to assume that this will turn out to be a syntactic gap in a relative clause construction. This would not be the only or even the most likely continuation of the sentence. That is, a sentence fragment with a missing argument (10) could turn out to be a simple clause (11), a sentential complement clause (12) with a dropped argument, or part of a relative clause (13). Alternatively, it could even turn out to be a scrambled sentence without any missing argument (14). Note that the use of the adnominal marker is not even exclusive to relative clauses, as shown in 12: here it is used to mark the sentential complement of the head noun 'fact'.

(10) Structural ambiguity of a gap

[ _ Yenghuy-lul hakkyo-eyse ... ]

Y-ACC school-at 
(11) Argument drop in a simple clause

[ _ Yenghuy-lul hakkyo-eyse manna-ss-ta]

Y-ACC school-at meet-PST-DECL

'(Someone) met Yenghuy at school.'

(12) Argument drop in a sentential complement clause

[ _ Yenghuy-lul hakkyo-eyse manna-n] sasil

Y-ACC school-at meet-ADN fact

'the fact that (someone) met Yenghuy at school'

(13) Subject relative clause

[ _ _ ${ }_{i}$ Yenghuy-lul hakkyo-eyse manna-n] sensayngnim ${ }_{i}$

Y-ACC school-at meet-ADN teacher

'the teacher who met Yenghuy at school'

(14) Scrambled sentence

[Yenghuy-lul hakkyo-eyse sensayngnim-i manna-ss-ta]

Y-ACC school-at teacher-NOM meet-PST-DECL

'The teacher met Yenghuy at school.'

Second, even if one were to assume that a gap could reliably indicate the presence of a filler, as is the case in 13, the encoding of a gap is not likely to burden working memory. In forward filler-gap dependencies, encoding a filler in working memory has been assumed to be difficult because an NP without a thematic role (or an incomplete dependency) imposes a working-memory burden (Gibson 1990). In a gap-filler dependency, however, a gap is a gap, with no phonetic or thematic content to encode. Although the parser might encode the missing thematic role of a relative clause verb or the event that it represents with a missing argument instead of a 'gap' per se in working memory, relative clause verbs occur immediately before the head noun in both subject and object relatives in Korean. We therefore predict that the relative clause region in a Korean relative clause construction will not elicit analogous ERP effects (i.e. sustained anterior negativity) to those elicited by English relative clause filler-gap constructions.

The filler-gap processing requirements outlined in $6 \mathrm{~b}, \mathrm{c}$ and 8 , by contrast, might be expected to cause similar processing difficulties in both forward filler-gap and backward gap-filler dependencies, despite ordering differences. A previous reading-time study of Korean backward gap-filler dependencies showed significantly longer reading times in ORs than in SRs, and this effect was most evident at the head noun position, where the parser has to locate an appropriate syntactic gap to associate with the filler (Kwon 2008b, Kwon et al. 2010). Likewise, in English forward filler-gap dependencies, there is greater processing difficulty in ORs than in SRs at the main verb position, where the parser has to locate an appropriate filler in working memory to associate with the gap (King \& Just 1991, King \& Kutas 1995, among others). Accordingly, we predict transient (left) anterior negativity and/or late positivity in response to ORs at the head noun position, similar to the responses to retrieval of a relevant filler (transient LAN response) and the integration of filler and gap (P600) in a forward filler-gap dependency. Moreover, any elicited late positivity may last throughout the sentence as it did in Ueno \& Garnsey 2008, as schematized in Table 3.

\subsection{Methods.}

MATERIALs. For the ERP experiment, eighty sets of subject (15) and object (16) relative clauses with possessive head nouns were constructed. ${ }^{14}$

${ }^{14}$ Relative clauses with possessive head nouns were selected to control for parallel grammatical function (Sheldon 1974). In the parallel grammatical function hypothesis (Sheldon 1974), relative clauses are pro- 


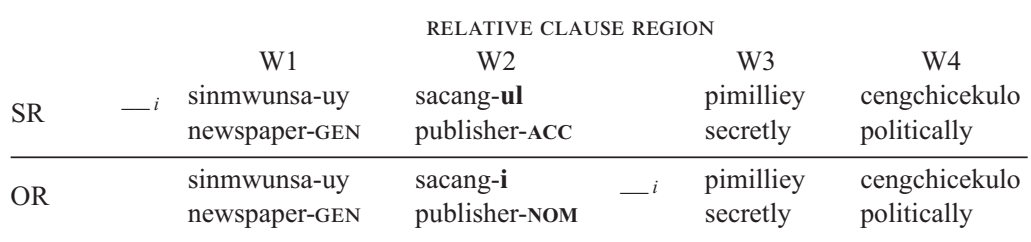

\begin{tabular}{|c|c|c|c|c|c|}
\hline \multirow[b]{2}{*}{$\mathrm{SR} / \mathrm{OR}$} & RC VERB & \multicolumn{4}{|c|}{ MAIN CLAUSE REGION } \\
\hline & $\begin{array}{l}\text { W5 } \\
\text { iyongha-n } \\
\text { exploit-ADN }\end{array}$ & $\begin{array}{c}\text { W6 } \\
\text { uywon-uy }_{i} \\
\text { senator-GEN }\end{array}$ & $\begin{array}{l}\text { W7 } \\
\text { samwusil-ey } \\
\text { office-to }\end{array}$ & $\begin{array}{l}\text { W8 } \\
\text { kkangphay-ka } \\
\text { gang-NOM }\end{array}$ & $\begin{array}{l}\quad \text { W9 } \\
\text { tulichyessta } \\
\text { attacked }\end{array}$ \\
\hline & noun & $\begin{array}{c}\uparrow \\
\text { AN and/or }\end{array}$ & o OR? & $\uparrow$ & \\
\hline
\end{tabular}

SR: 'Gangs attacked the office of the senator who secretly took advantage of the publisher of the newspaper for political purposes.'

OR: 'Gangs attacked the office of the senator who the publisher of the newspaper secretly took advantage of for political purposes.'

TABLE 3. Summary of predictions.

(15) SR experimental sentences

[ $\ldots i$ sinmwunsa-uy sacang-ul pimilliey cengchicekulo iyongha-n] newspaper-GEN publisher-ACC secretly politically exploit-ADN uywon-uy samwusil-ey kkangphay-ka tulichyessta senator-GEN office-to gang-NOM attacked

SR: 'Gangs attacked the office of the senator who secretly took advantage of the publisher of the newspaper for political purposes.'

(16) OR experimental sentences [sinmwunsa-uy sacang-i _ _ ${ }_{i}$ pimilliey cengchicekulo iyongha-n] newspaper-GEN publisher-NOM secretly politically exploit-ADN uywon-uy samwusil-ey kkangphay-ka tulichyessta senator-GEN office-to gang-NOM attacked

OR: 'Gangs attacked the office of the senator who the publisher of the newspaper secretly took advantage of for political purposes.'

In this study, we were interested in syntactic aspects of relative clause processing. ${ }^{15}$ For this reason, we intentionally used out-of-the-blue sentences with no supporting context (but see Kwon et al. 2010 for the processing of Korean relative clauses both with and without facilitating context) in order to avoid the influence of discourse pragmatic support. We also made our relative clauses semantically reversible by including two human arguments in order to avoid semantically guided parsing. In addition, we conducted a norming study to control for the plausibility of the SRs and ORs, following Miyamoto and Nakamura (2003), with an aim to ensure that the plausibility of the

cessed more easily when the head noun carries the same grammatical function in both main and relative clauses. Thus, for example, SRs with subject head nouns and ORs with object head nouns have an advantage over ORs with subject head nouns and SRs with object head nouns, respectively. SRs and ORs with possessive head nouns do not share this confound, since both constructions involve different grammatical roles for the head noun in the relative and main clauses.

${ }^{15}$ A relative clause with a possessive head noun is structurally ambiguous in Korean, such that the relative clause could be interpreted as modifying either the first or the second NP (e.g. 'senator-GEN' or 'office-to' in 15 and 16). To remove this ambiguity, only inanimate NPs (e.g. 'office-to') were used as the second noun, while a human head noun (e.g. 'senator-GEN') was required by the relative clause verb. 
events denoted in the experimental sentences would not bias one interpretation over the other. One hundred and forty-four native Korean speakers living in Korea participated in the norming study. Sentences were created by replacing the gap with its associated head noun in each of eight sets of SR and OR conditions. For example, for SRs (15) and ORs (16), sentences like 17 and 18 were created.

(17) Norming sentence generated from SR condition

uywon-i sinmwunsa-uy sacang-ul pimilliey cengchicekulo

senator-NOM newspaper-GEN publisher-ACC secretly politically iyonghayssta

exploit

'The senator secretly took advantage of the publisher of the newspaper for political purposes.'

(18) Norming sentence generated from OR condition

sinmwunsa-uy sacang-i uywon-ul pimilliey cengchicekulo

newspaper-GEN publisher-NOM senator-ACC secretly politically

iyonghayssta

exploit

'The publisher of the newspaper secretly took advantage of the senator for political purposes.'

A norming study for another experiment with two long-distance dependency conditions was included in the same experimental paradigm. The norming sentences were split into four lists using a Latin square design. Participants saw one sentence from each SR and OR pair (e.g. 17 or 18) and rated the plausibility of each sentence on a scale of 1-5 ( 1 if it sounded plausible and 5 if it sounded unlikely). Three subjects did not complete the questionnaire and thus were excluded from the analysis. The means for plausibility were 2.5 for the sentences formed from SRs and 2.6 for the sentences formed from ORs. ${ }^{16}$ A student's $t$-test showed that this difference was not significant $(t(140)=2.59, p=0.1)$.

The ERP study was run concurrently with another study in the same experimental sessions. Thus, eighty further sets of object relatives with different head noun types ('The painter who the representative of the gallery evaluated highly at the international exhibition gained the attention of the world') and minimal-pair adjunct clause sentences with dropped object arguments ('Because the representative of the gallery evaluated $\left[\mathrm{him}_{i}\right]$ highly at the international exhibition, the painter $_{i}$ gained the attention of the world') were included. In other words, two other long-distance dependency conditions - one syntactic and the other referential—were presented to participants during the same experimental sessions. Moreover, since at the time of the study there were no previously reported ERP results available for Korean to which our experimental results could be compared, another 210 sets of filler sentences were included to elicit standard N400, P600, and LAN effects. These filler sentences consisted of seventy sets each of phrase structure violations of headedness (the use of prepositions instead of postpositions, which are required by the rigidly head-final structure of Korean) (19), semantic incongruity violations (20), and so-called 'scrambled' sentences in which a direct object was fronted to the beginning of the sentence (21). ${ }^{17}$

\footnotetext{
${ }^{16}$ The experimental stimuli were newspaper-style sentences, and the relatively low acceptability ratings may also be due to their complex structure (see ns. 14, 15, and 21) and high-level vocabulary.

17 Thus, all told, participants saw forty subject relative sentences, eighty object relative sentences, forty sentences containing adjunct clauses with dropped object arguments, thirty-five sentences with scrambled direct objects, thirty-five sentences containing a headedness violation, thirty-five sentences containing a se-
} 
(19) Phrase structure violations

a. Grammatical control

emma-ka ocen-ey kongwon-ulo sanchayk-ul ka-si-ess-ta

Mom-NOM morning-at the.park-to walk-ACC go-HON-PST-DECL

'Mom went to the park for a walk.'

b. Ungrammatical sentence: headedness violation

emma-ka ocen-ey ulo-kongwon sanchayk-ul ka-si-ess-ta

Mom-NOM morning-at to-the.park walk-ACC go-HON-PST-DECL

'*Mom went the park to for a walk.'

(20) Semantic congruity violations

a. Congruous control

achim-ey salamtul-i pap-ul mek-ess-ta

morning-in people-NOM rice-ACC eat-PST-DECL

'In the morning, people ate a meal.'

b. Incongruous sentence

achim-ey salamtul-i chayk-ul mek-ess-ta

morning-in people-NOM book-ACC eat-PST-DECL

'\#In the morning, people ate a book.'

(21) Scrambling

a. Canonical word order sentence

ku yuchiwon-uy woncang-i hakwon-uy nyencwung hayngsa-ey

that kindergarten-GEN principal-NOM school-GEN annual event-to

hakpwumotul-ul chotayhay-ss-ta

parents-ACC invite-PST-DECL

'The principal of the kindergarten invited the parents to the annual school event.'

b. Scrambled sentence

hakpwumotul $_{i}$-ul ku yuchiwon-uy woncang-i hakwon-uy

parents-ACC that kindergarten-GEN principal-NOM school-GEN nyencwung hayngsa-ey __i ${ }_{i}$ chotayhay-ss-ta

annual event-to invite-PST-DECL

' The parents, the principal of the kindergarten invited _ to the annual school event.'

All experimental and filler sentences were split into two lists of 370 sentences each using a Latin square design. These were further divided into twelve sublists, of which ten contained thirty-one sentences and the remaining two contained thirty sentences. The sentences in each list were pseudo-randomized, such that sentences from the same condition never appeared consecutively. In addition, the stimuli were presented in a different random order for every participant to prevent order-related effects.

PARTICIPANTS. Twenty-two native Korean speakers were paid \$10/hour for their participation in the ERP study (fourteen females, eight males). ${ }^{18}$ At the time of the experiment, all participants were between the ages of twenty-two and thirty-one (mean age:

mantic violation, and 105 well-formed monoclausal sentences with no dependency formation. If anything, the overrepresentation of object dependencies (forward syntactic (scrambling), backward syntactic (ORs), and backward referential (adjunct clauses with dropped objects)) in the stimulus set should have facilitated the processing of ORs compared to SRs. However, as the results show (see §2.3), this was not the case.

${ }^{18}$ The total number of participants actually run was twenty-four. However, two participants were excluded from analyses due to excessive EEG artifacts. 
twenty-five) and were enrolled in graduate school or in English classes at UCSD Extension. The average length of stay in the US was thirteen months (range of length of stay: two months to 3.5 years). All participants were right-handed with no neurological disorders and normal or corrected-to-normal vision.

Procedures. Participants were run in a single session lasting about 2.5 hours, including preparation. Sentences were presented visually in Korean Hangul (phonetic) script in the center of a monitor screen, one ejel (a writing unit typically composed of one free morpheme with additional dependent morpheme(s), e.g. 'singer-NOM') at a time. Each ejel was presented for $300 \mathrm{~ms}$ with a $500 \mathrm{~ms}$ stimulus onset asynchrony (SOA). ${ }^{19}$ The interstimulus interval between sentences was $3000 \mathrm{~ms}$, and subjects were given as much rest as they wished between sublists. Yes/no comprehension questions were presented at the end of every five sentences on average to maintain participants' attention. The comprehension questions focused on the content of the immediately preceding sentence; both filler and experimental sentences were tested. For example, the comprehension question in 22 immediately followed experimental sentence 15 .

(22) Comprehension question

sinmwunsa-uy sacang-i uywon-ul cengchicekulo

newspaper-GEN publisher-NOM senator-ACC politically

iyonghaysssupnikka?

exploited

'Did the publisher of the newspaper take advantage of the senator?'

Each comprehension question appeared $1000 \mathrm{~ms}$ after the offset of the sentence-final word and remained on the screen until participants responded by pressing hand-held buttons. The response hand was counterbalanced to control for dominance. The next sentence started $2000 \mathrm{~ms}$ after the response. There was a practice session with seven sentences before the experiment.

ELECTROPHYSIOLOGICAL RECORDING. The electroencephalogram (EEG) was recorded from twenty-six tin electrodes mounted geodesically in an electro-cap. These sites included midline prefrontal (MiPf), left and right lateral prefrontal (LLPf and RLPf), left and right medial prefrontal (LMPf and RMPf), left and right lateral frontal (LLFr and RLFr), left and right medial frontal (LMFr and RMFr), left and right medial lateral frontal (LDFr and RDFr), left and right medial central (LMCe and RMCe), midline central (MiCe), left and right medial lateral central (LDCe and RDCe), left and right lateral temporal (LLTe and RLTe), left and right medial lateral parietal (LDPa and RDPa), midline parietal (MiPa), left and right lateral occipital (LLOc and RLOc), left and right medial occipital (LMOc and RMOc), and midline occipital (MiOc). Each electrode was referenced on-line to the reference electrode on the left mastoid. To monitor blinks and eye movements, electrodes were placed on the outer canthi and under each eye, and were

\footnotetext{
${ }^{19}$ Since at the time of this study there were no previous ERP results for Korean reported in the literature, the presentation rate was based on gaze durations in eye-tracking studies and the responses of four participants in pilot experiments. The average reading time for first-pass reading per ejel in eye-tracking studies is about $400 \mathrm{~ms}$ (Kwangil Choi, Yoonhyoung Lee, and Youngjin Kim, p.c.). In pilot experiments, volunteers were presented with experimental sentences in blocks at different presentation rates (400 ms duration with $650 \mathrm{~ms} \mathrm{SOA}, 300 \mathrm{~ms}$ duration with $500 \mathrm{~ms}$ SOA, and $200 \mathrm{~ms}$ duration with $400 \mathrm{~ms} \mathrm{SOA}$ ) and rated each presentation speed in terms of their understanding of the sentences and the naturalness of the reading speed. The presentation order of each block was different for each participant. Participants reported that although they could understand sentences at the fastest presentation rate (200 ms presentation with $400 \mathrm{~ms} \mathrm{SOA})$, they felt most comfortable and natural with presentation rates of $500 \mathrm{~ms}$ SOA.
} 
referenced to the left mastoid. Impedances were kept below $5 \mathrm{~K} \Omega$. The EEG was amplified with Nicolet amplifiers, digitized at a sampling rate of $250 \mathrm{~Hz}$.

DATA ANALYSIS. For transient effects, measurements were taken of single-word ERP averages, which consisted of $1000 \mathrm{~ms}$ epochs, including a $100 \mathrm{~ms}$ prestimulus baseline. For longer-lasting effects, measurements were taken of two-word averages, which consisted of $1700 \mathrm{~ms}$ epochs $(2 \times 500 \mathrm{~ms} \mathrm{SOA}$, a $400 \mathrm{~ms}$ prestimulus baseline, and the first $300 \mathrm{~ms}$ of the following (third) word). Trials contaminated by excessive muscle activity, amplifier blocking, or eye movements were discarded off-line before averaging. On average, $4 \%$ and $9 \%$ of trials were rejected for single- and two-word averages, respectively. The averaged data were algebraically rereferenced to the mean of the activity at the two mastoids. For purposes of visualization only, ERP waves were smoothed using a low-pass filter with a cut-off frequency of $5 \mathrm{~Hz}$.

The data were submitted to a full analysis, that is, an overall ANOVA with repeated measures of experimental condition (SR vs. OR) and electrodes (twenty-six levels). In addition, a distributional analysis was conducted, including experimental condition (SR vs. OR), hemisphere (left vs. right), laterality (lateral vs. medial), and anteriority (four levels: prefrontal vs. frontal vs. temporoparietal vs. occipital) as factors. Electrodes included were left and right lateral prefrontal (LLPf and RLPf), left and right medial prefrontal (LMPf and RMPf), left and right lateral frontal (LLFr and RLFr), left and right medial frontal (LDFr and RDFr), left and right lateral temporal (LLTe and RLTe), left and right medial lateral parietal (LDPa and RDPa), left and right lateral occipital (LLOc and RLOc), and left and right medial occipital (LMOc and RMOc). To corroborate smaller local effects, an ANOVA was performed on quadrant regions of electrodes (left anterior: LLPf, LLFr, LMPf, LDFr; right anterior: RLPf, RLFr, RMPf, RDFr; left posterior: LLTe, LLOc, LDPa, LMOc; right posterior: RLTe, RLOc, RDPa, RMOc) or on individual electrodes. All analyses were run on mean amplitudes of predetermined latency intervals based on prior research (N100: 80-120 ms; P200: 150-250 ms; P600: 500-800 ms; N400: 300-600 ms; LAN: 300-600 ms) unless otherwise noted. The Huynh-Feldt (Huynh \& Feldt 1976) correction for lack of sphericity was applied, and corrected $p$-values are reported with the original degrees of freedom.

2.3. Results. The mean correct response rates to comprehension questions following SRs (15) and ORs (16) did not differ significantly: 70\% vs. $68 \%$, respectively. ${ }^{20}$ Comprehension accuracy was higher for filler sentences: $94 \%$ for sentences with and without phrase structure violations (19), 95\% for sentences with and without semantic incongruity (20), and $85 \%$ for sentences with and without scrambling (21). ${ }^{21}$

\footnotetext{
${ }^{20}$ A referee asked why there was no difference in the accuracy rate of responses to the comprehension questions following SRs and ORs despite the reported difference in brain responses. It is important to bear in mind that comprehension questions are a measure of off-line language processing, while ERPs are a measure of ongoing brain activity. The use of a subset of the same experimental sentences in a prior eye-tracking study, another on-line measure of language processing, yielded results comparable to the ERP results reported here: while ORs were read more slowly than SRs, there was no difference in the correct answer rate between the two conditions (Kwon et al. 2010). This then suggests that comprehension questions are not a measure sensitive enough to detect the processing asymmetry of SRs and ORs in these experiments. Moreover, because ERP responses are in general more sensitive than other behavioral measures, it is often the case that ERPs show significant differences or correlations where behavioral measures show none; see McLaughlin et al. 2004 for just one such example.

${ }^{21}$ We believe that the rather low comprehension accuracy rates for our experimental sentences are an inevitable and direct consequence of the design we chose for this study and of our attempts to eliminate potential confounds from it. As discussed in $\$ 2.2$ (see also ns. 14-16), our experimental stimuli were (i) highregister, complex newspaper-style sentences that (ii) avoided the use of supporting context to force syntactic
} 
Recall that the focus of this experiment was the processing of backward (gap-filler) dependencies in Korean relative clauses; the results were then to be compared with the processing of forward dependencies in English relative clauses. To investigate the effects on the ERP record of an unfilled gap in need of integration with a subsequent filler, we planned to examine ERP responses to SRs and ORs in three regions: relative clause, head noun, and main verb regions, as shown in Table 3. Before presenting the main experimental findings with regard to relative clauses, however, we first present the results for the filler sentences, which help to provide some context for the interpretation of the experimental results.

Filler SENTENCES With PHRASE STRUCtURE Violations: P600. The ungrammatical filler sentences with prepositions in place of postpositions ('*to-the.park', 19b) elicited a positive-going ERP in comparison to the grammatical controls with postpositions ('the.park-to', 19a). This effect was widely distributed across the scalp (Figure 2). ${ }^{22}$ The full ANOVA in the 500-800 ms latency range with all twenty-six electrodes showed a main effect of grammaticality (see Table 4 for a summary of the ANOVA results). In the distributional analysis, there was again a significant main effect of grammaticality and a significant interaction of grammaticality, laterality, and anteriority; while the relative difference in amplitude of the late positivity in response to ungrammatical vs. grammatical sentences was constant over lateral electrodes, it was larger over the back than over the front of the head at medial electrodes (Fig. 2C).

\begin{tabular}{lll} 
FULL ANALYSIS & $\begin{array}{l}500-800 \text { MS POST-ONSET OF '*to-the.park' vs. 'the.park-to' } \\
\text { grammaticality }\end{array}$ & $F(1,21)=20.32, p<0.0002$ \\
\hline \multirow{2}{*}{ DISTRIBUTIONAL ANALYSIS } & $\begin{array}{l}\text { grammaticality } \\
\text { grammaticality } \times \text { laterality } \times \text { anteriority }\end{array}$ & $\begin{array}{l}F(1,21)=21.66, p<0.0001 \\
F(3,63)=9.58, p<0.0004\end{array}$
\end{tabular}

TABLE 4. Filler sentences with vs. without phrase structure violations.

Filler SENTENCES With SEMANTIC InCONGRUity: N400. The semantically incongruous filler sentences (e.g. 'In the morning, people ate a book', 20b) elicited a negative-going ERP in comparison to the congruous controls (e.g. 'In the morning, people ate a meal', 20a), as seen in Figure 3. The full ANOVA in the 300-600 ms latency range with all twenty-six electrodes showed a main effect of congruity and a significant interaction of congruity and electrodes (see Table 5 for a summary of the ANOVA results). In the distributional analysis, there was again a main effect of congruity, a significant interaction of congruity and laterality caused by larger differences in amplitude between congruous and incongruous sentences at medial than at lateral electrodes, and an interaction of congruity and anteriority caused by larger differences in amplitude over the occipital and temporoparietal regions of the scalp than over prefrontal and frontal regions (Fig. 3C). In addition, on visual inspection, the difference looked slightly larger over the right than over the left side of the head, and this impression was confirmed by an interaction of congruity and hemisphere. Overall, this response had the latency, morphology, and scalp distribution typical of an N400 effect.

processing and (iii) featured possessive head nouns with different grammatical functions in the main and relative clause and (iv) two semantically reversible human discourse referents that were moreover (v) balanced for plausibility in a prior norming study and (vi) referred to by semantically related occupational titles (e.g. conductor vs. vocalist). Taken together, these considerations rendered experimental sentences difficult (though certainly not impossible) to process and to remember for purposes of answering our intermittent comprehension questions correctly.

${ }^{22}$ Color versions of Figs. 2-4 and 6-8 can be accessed at http://muse.jhu.edu/journals/language/v089 /89.3.kwon01.html. 


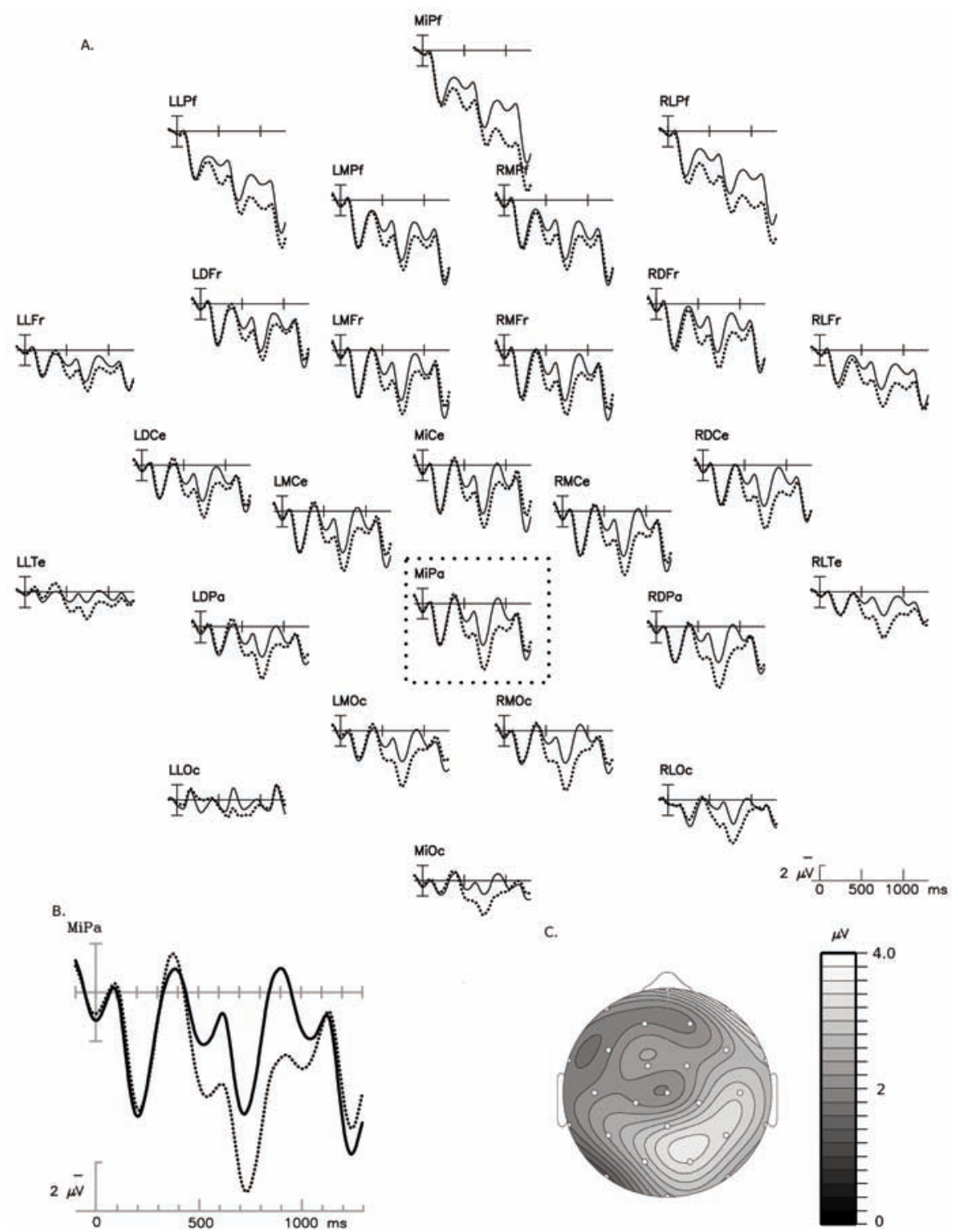

FIGURE 2. A. Grand average ERP waveforms in response to grammatical ('the.park-to'; solid line -) and ungrammatical (“*to-the.park'; dotted line *...) phrases at all twenty-six electrode sites. B. Grand average ERP waveforms for grammatical (-) and ungrammatical ( …) phrases at the medial parietal electrode (the electrode in the dotted square in A). C. Topographic scalp isovoltage map of the mean difference (ungrammatical - grammatical conditions, $500-800 \mathrm{~ms}$ ).

\begin{tabular}{lll}
\multicolumn{2}{c}{$300-600$ MS POST-ONSET OF '\#ate a book' vs. 'ate a meal' } \\
FULL ANALYSIS & $\begin{array}{l}\text { congruity } \\
\text { congruity } \times \text { electrodes }\end{array}$ & $F(1,21)=5.21, p<0.003$ \\
\hline \multirow{2}{*}{ DISTRIBUTIONAL ANALYSIS } & $\begin{array}{l}\text { congruity } \\
\text { congruity } \times \text { laterality }\end{array}$ & $F(1,21)=4.52, p<0.0045$ \\
& $\begin{array}{l}\text { congruity } \times \text { anteriority } \\
\text { congruity } \times \text { hemisphere }\end{array}$ & $F(1,21)=6.81, p<0.016$ \\
& $F(1,21)=5.63, p<0.027$
\end{tabular}

TABLE 5. Filler sentences with vs. without semantic congruity violations. 


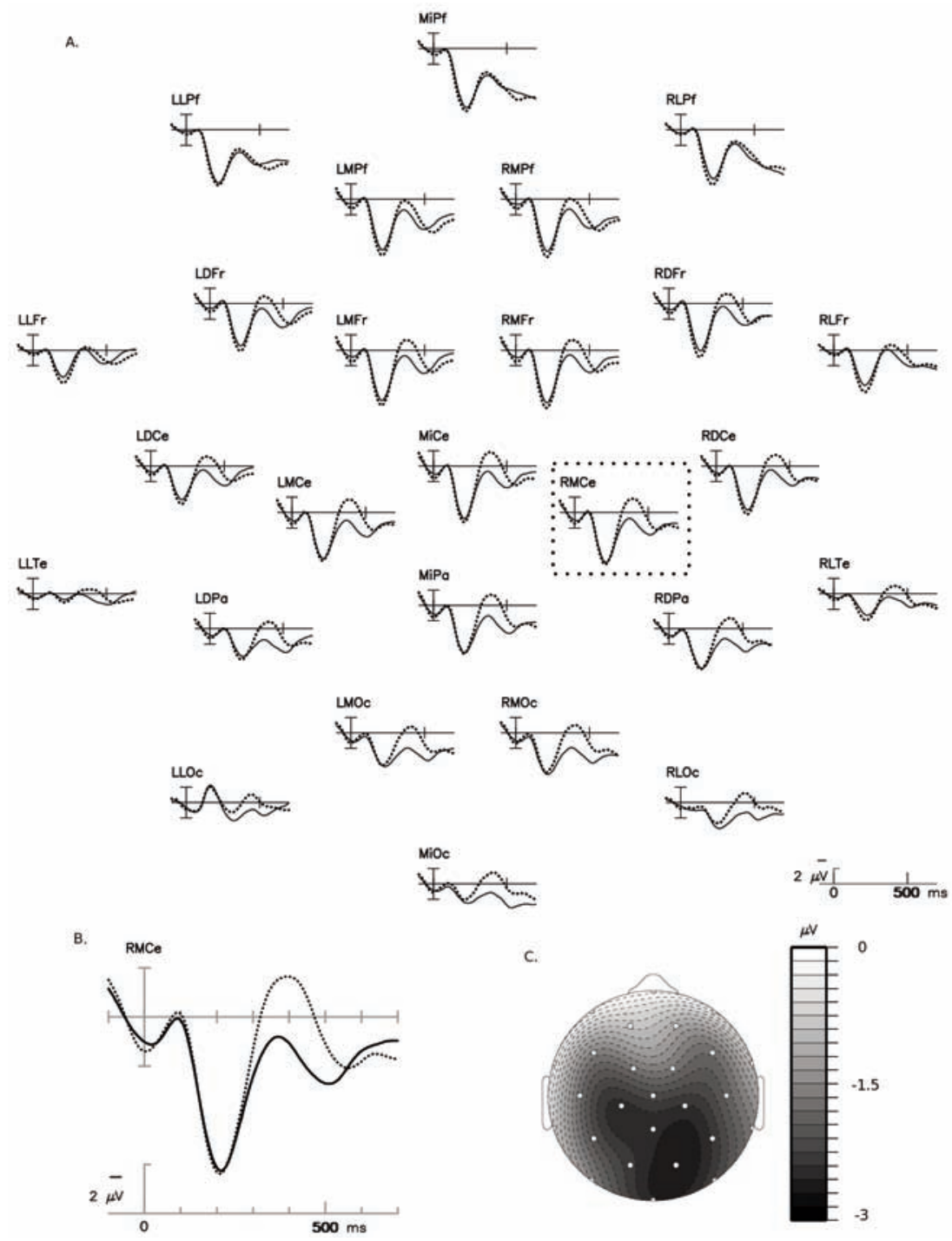

FIGURE 3. A. Grand average ERP waveforms in response to congruous (meal-ACC ate 'ate a meal'; solid line -) and incongruous (book-ACC ate 'ate a book'; dotted line $\cdots$...) sentence endings at all twenty-six electrode sites. B. Grand average ERP waveforms for congruous (-) and incongruous ( (..) endings at the right medial central electrode (the electrode in the dotted square in A). C. Topographic scalp isovoltage map of the mean difference (incongruous - congruous conditions, $300-600 \mathrm{~ms}$ ).

FILLER SENTENCES WITH SCRAMBLING: LAN. Scrambled sentences (21b) elicited more negativity relative to sentences in canonical word order (21a), starting approximately $300 \mathrm{~ms}$ post-stimulus onset of the subject 'principal-NOM' in $21 \mathrm{~b}$, and continuing into the next word 'school-GEN'. ${ }^{23}$ On visual inspection, this negativity appeared to have a symmetrical anterior maximum (Figure 4). Since we had predicted that this manipulation

${ }^{23}$ For this comparison, we used nominative NPs in different sentence positions (following Ueno \& Kluender 2003) rather than the same NP in nominative vs. accusative case (or topic-marked) in the same sentence position (following Hagiwara et al. 2007). Since the two methods of comparison have yielded equivalent results across studies, we do not believe that this difference is of any consequence. 
would elicit a LAN effect, we first measured the response to the subject noun 'principalNOM' in a latency window of 300-600 ms. There was a significant main effect of scrambling in the full analysis (see Table 6 for a summary of the ANOVA results). This was also the case in the distributional analysis, which additionally revealed an interaction of scrambling and laterality caused by larger differences over medial than over lateral electrodes, as well as a marginal interaction of scrambling, hemisphere, laterality, and anteriority. This four-way interaction appears to have been caused by the fact that the negative response was largest over anterior electrodes of the left medial array (Fig. 4A,C).

We next measured the response in a latency window of 800-1100 ms post-stimulus onset of the subject noun 'principal-NOM': in other words, 300-600 ms post-stimulus onset of the following word, 'school-GEN' (21b), but without rebaselining. There was again a main effect of scrambling in both the full analysis and the distributional analysis, as well as a three-way interaction of scrambling, hemisphere, and laterality, caused by the larger difference over right medial and lateral and left medial electrodes than over left lateral electrodes (Fig. 4D).

However, when we rebaselined the ERPs to the second word, 'school-GEN', the negative effect disappeared in both the full and the distributional analysis. We therefore decided to see if it was possible to treat the negativity in response to these two words as sustained in nature, as we had in fact anticipated, and measured it from 300-1100 ms post-stimulus onset of 'principal-NOM'. This resulted in a significant main effect in both the full ANOVA and the distributional analysis. The distributional analysis also yielded a marginal interaction of scrambling and laterality, due to a larger difference between conditions over medial than over lateral regions of the scalp, and a marginal interaction of scrambling, hemisphere, and laterality. This was again likely caused by the larger difference over right medial and lateral and left medial electrodes than over left lateral electrodes (Fig. 4D).

\begin{tabular}{|c|c|c|}
\hline FULL ANALYSIS & $\begin{array}{l}300-600 \text { MS POST-ONSET OF 'principal-NOM' } \\
\text { scrambling }\end{array}$ & $F(1,21)=4.4, p<0.049$ \\
\hline DISTRIBUTIONAL ANALYSIS & $\begin{array}{l}\text { scrambling } \\
\text { scrambling } \times \text { laterality } \\
\text { scrambling } \times \text { hemisphere, laterality } \times \text { anteriority }\end{array}$ & $\begin{array}{l}F(1,21)=5.44, p<0.03 \\
F(1,21)=4.91, p<0.038 \\
F(1,21)=2.45, p<0.07\end{array}$ \\
\hline \multicolumn{3}{|c|}{$800-1100$ MS POST-ONSET OF 'principal-NOM' (without rebaselining to the next word) } \\
\hline FULL ANALYSIS & scrambling & $F(1,21)=4.85, p<0.039$ \\
\hline DISTRIBUTIONAL ANALYSIS & $\begin{array}{l}\text { scrambling } \\
\text { scrambling } \times \text { hemisphere } \times \text { laterality }\end{array}$ & $\begin{array}{l}F(1,21)=7.95, p<0.01 \\
F(1,21)=5.74, p<0.026\end{array}$ \\
\hline \multicolumn{3}{|c|}{$800-1100$ MS POST-ONSET OF 'principal-NOM' (with rebaselining to the next word) } \\
\hline FULL ANALYSIS & scrambling & $F(1,21)=0.02$, n.s. \\
\hline DISTRIBUTIONAL ANALYSIS & scrambling & $F(1,21)=0.01$, n.s. \\
\hline FULL ANALYSIS & $\begin{array}{l}300-1100 \text { MS POST-ONSET OF 'principal-NOM' } \\
\text { scrambling }\end{array}$ & $F(1,21)=6.72, p<0.017$ \\
\hline DISTRIBUTIONAL ANALYSIS & $\begin{array}{l}\text { scrambling } \\
\text { scrambling } \times \text { laterality } \\
\text { scrambling } \times \text { hemisphere } \times \text { laterality }\end{array}$ & $\begin{array}{l}F(1,21)=6.5, p<0.019 \\
F(1,21)=3.84, p<0.063 \\
F(1,21)=4.01, p<0.058\end{array}$ \\
\hline
\end{tabular}

TABLE 6. Filler sentences with vs. without scrambling.

There were somewhat surprisingly no subsequent ERP differences - neither a transient LAN nor a late positive response - to the words immediately preceding (hayngsa$e y$ 'event-to') or following (chotayhay-ss-ta 'invite-PST-DECL', that is, the sentence-final main clause verb) the purported gap position in scrambled sentences (21b). 


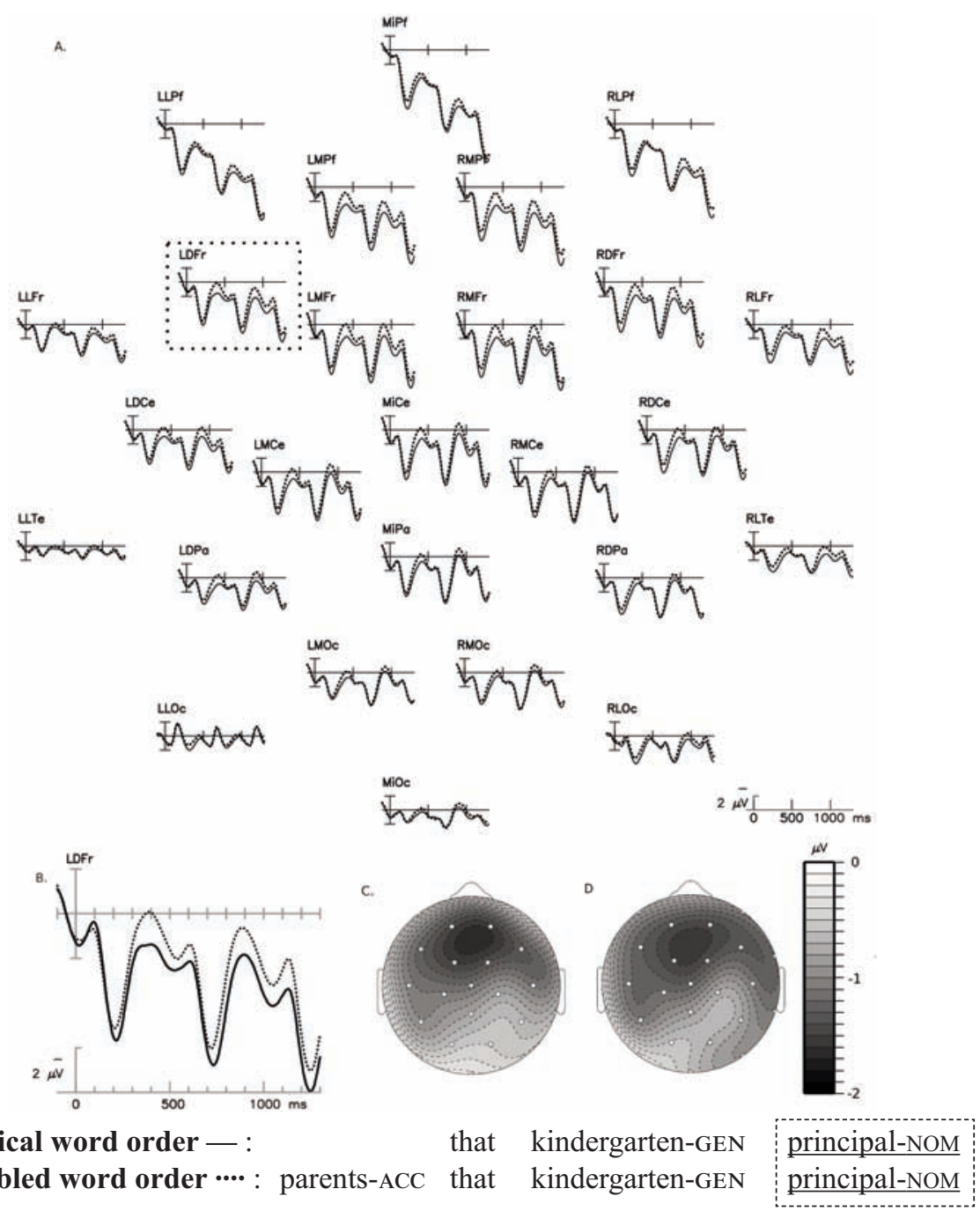

Canonical word order - :

that kindergarten-GEN

Scrambled word order $\cdots .$. : parents-ACC that kindergarten-GEN

principal-NOM

FIGURE 4. A. Grand average ERP waveforms in response to canonical (solid line - ) and scrambled (dotted line...$)$ ) word order sentences at the nominative-marked NP, all twenty-six electrode sites. B. Grand average ERP waveforms for canonical (-) and scrambled (...) word orders at the left medial frontal electrode (the electrode in the dotted square in A). C. Topographic scalp isovoltage map of the mean difference at 'principalNOM' (scrambled - canonical word order conditions, $300-600 \mathrm{~ms}$ ). D. Topographic scalp isovoltage map of the mean difference at 'school-GEN' (scrambled - canonical word order conditions, $800-1100 \mathrm{~ms}$ post-stimulus onset of 'principal-NOM').

ERP RESULTS FOR SR AND OR SENTENCES. As an illustration of the overall pattern, Figure 5 shows the ERP responses elicited at left lateral electrodes by ORs vs. SRs in the sentence-initial relative clause region of the stimulus materials (including the head noun, the last word of the average). Visual inspection suggests that ORs elicited greater negativity than SRs at two sentence positions: the second and third words of the prenominal relative clause ('publisher-NOM secretly'; see Table 3), and again at the head noun ('senator-GEN'). Each of these effects is discussed in detail in what follows, using ERP responses obtained over the entire head. 


\section{Left lateral frontal}

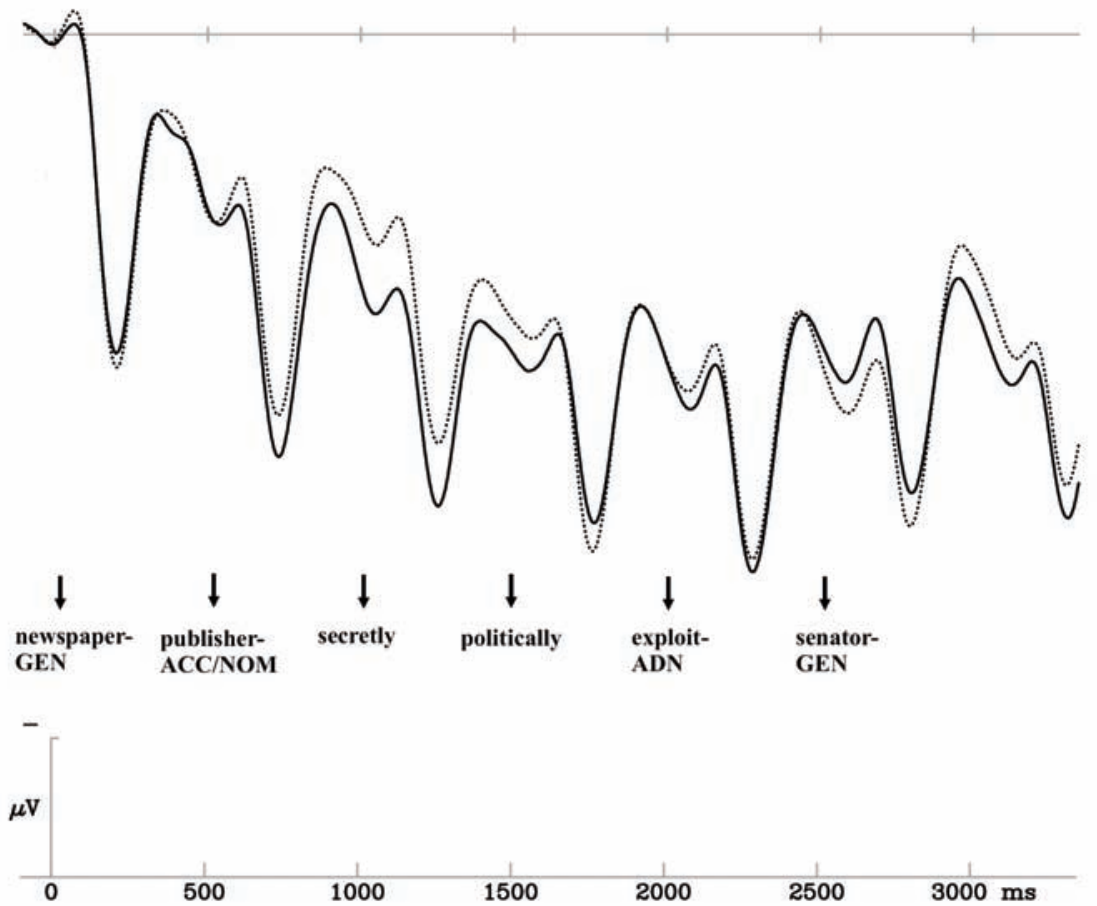

FIGURE 5. Grand average ERP waveforms in response to NP-ACC/NOM in subject ("publisher-ACC secretly politically exploit-ADN senator-GEN'; solid line -) and object relative clauses ('publisher-NOM secretly politically exploit-ADN senator-GEN'; dotted line $\cdots \cdot$ ) at the left lateral frontal electrode.

RELATIVE CLAUSE REGION PRIOR TO THE RELATIVE CLAUSE VERB. Recall the structure of the relative clause (Table 3): W1 was always a noun in genitive case associated with W2, which appeared in the nominative if the relative clause gap was the object (OR) and in the accusative if the relative clause gap was the subject (SR). Visual inspection of the ERPs in response to the W2 position (see Table 3) revealed a larger broad frontal negativity to the OR ('publisher-NOM', 16) than to the SR condition ('publisher-ACC', 15), particularly at lateral electrodes. ${ }^{24}$ This effect continued throughout the response to W3, 'secretly', as shown in Figure 6.

To corroborate apparent early effects (Fig. 6B), mean voltage measures were taken in the N100 (80-120 ms) and P200 (150-250 ms) latency windows. These measures were subjected to both full and distributional omnibus ANOVAs (see Table 7 for a summary of the ANOVA results). In the analysis of the 80-120 ms interval, there was no significant effect either in the full analysis (relative clause type $\times 26$ electrodes) or in the distributional analysis (relative clause type $\times$ hemisphere $\times$ laterality $\times$ anteriority). With regard to apparent P200 effects, in the 150-250 ms interval, by contrast, there was a significant main effect of relative clause type in both the full and the distributional analyses, indicating that the OR condition began to elicit early negativity over much of the scalp.

${ }^{24} \mathrm{SRs}$ and ORs did not differ significantly at $\mathrm{W} 1 \mathrm{in}$ any of the time windows of $0-100 \mathrm{~ms}(F(1,21)=1.01$, n.s. $), 100-200 \mathrm{~ms}(F(1,21)=0.44$, n.s. $), 200-300 \mathrm{~ms}(F(1,21)=0.03$, n.s. $), 300-400 \mathrm{~ms}(F(1,21)=0.14$, n.s. $)$, or $400-500 \mathrm{~ms}(F(1,21)=0.42$, n.s. $)$. 


\begin{tabular}{|c|c|c|}
\hline \multicolumn{3}{|c|}{ 80-120 MS POST-ONSET OF W2 'publisher-ACC/NOM' } \\
\hline FULL ANALYSIS & $\mathrm{RC}$ type & $F(1,21)=1.23$, n.s. \\
\hline \multicolumn{3}{|c|}{ 150-250 MS POST-ONSET OF W2 'publisher-ACC/NOM’' } \\
\hline FULL ANALYSIS & RC type & $F(1,21)=5.14, p<0.04$ \\
\hline DISTRIBUTIONAL ANALYSIS & $\mathrm{RC}$ type & $F(1,21)=5.83, p<0.03$ \\
\hline \multicolumn{3}{|c|}{ 300-600 MS POST-ONSET OF W2 'publisher-ACC/NOM’' } \\
\hline FULL ANALYSIS & RC type & $F(1,21)=1.26$, n.s. \\
\hline DISTRIBUTIONAL ANALYSIS & $\mathrm{RC}$ type & $F(1,21)=1.46$, n.s. \\
\hline \multicolumn{3}{|c|}{ 800-1100 MS POST-ONSET OF W2 'publisher-ACC/NOM’ } \\
\hline FULL ANALYSIS & $\mathrm{RC}$ type & $F(1,21)=0.001$, n.s. \\
\hline DISTRIBUTIONAL ANALYSIS & $\mathrm{RC}$ type & $F(1,21)=0.12$, n.s. \\
\hline \multicolumn{3}{|c|}{ 300-1100 MS POST-ONSET OF W2 'publisher-ACC/NOM’ } \\
\hline FULL ANALYSIS & RC type $\times$ electrodes & $F(25,525)=3.05, p<0.001$ \\
\hline DISTRIBUTIONAL ANALYSIS & $\mathrm{RC}$ type $\times$ anteriority & $F(3,63)=5.16, p<0.03$ \\
\hline LEFT LATERAL FRONTAL ELECTRODE & $\mathrm{RC}$ type & $F(1,21)=5.33, p<0.032$ \\
\hline RIGHT LATERAL FRONTAL ELECTRODE & $\mathrm{RC}$ type & $F(1,21)=3.96, p<0.06$ \\
\hline
\end{tabular}

TABLE 7. SR vs. OR experimental sentences: relative clause region prior to the relative clause verb.

To quantify later effects, we first measured the response to each word separately, as we had done in the scrambling comparison. Although we had actually not expected a sustained negativity in response to the relative clause region of our experimental sentences (§2.1), we had allowed for it as a logical possibility (9a). We therefore measured each of the two words ('publisher-NOM secretly') that appeared to elicit anterior negativity in the relative clause region (Fig. 5) for standard LAN effects in a latency window of 300-600 ms and 800-1100 ms post-stimulus onset of 'publisher-NOM', respectively (i.e. without rebaselining at the second word, 'secretly'). However, neither of these measurements produced significant effects in either the full or the distributional analysis.

We therefore conducted an analysis in a time window of 300-1100 ms post-stimulus onset of 'publisher-NOM/ACC' in order to encompass both words simultaneously. Measuring the negativity in this way yielded a significant interaction of relative clause type and electrode in the full analysis and a corresponding interaction of relative clause type and anteriority in the distributional analysis. This was due to more pronounced negativity in response to ORs over lateral frontal regions of the scalp (Fig. 6C). Statistical analyses of the sixteen individual electrodes included in the distributional analysis revealed significant main effects of relative clause type at left lateral frontal and right lateral frontal electrodes (all other $F_{\mathrm{S}}<2$ ) (Fig. 6C).

Overall, these effects indicated that ORs elicited more anterior negativity than SRs in the relative clause region. A significant main effect in the P200 time window indicated that this negativity in response to ORs tended to onset early ( $200 \mathrm{~ms})$; significant interactions in the longer time window of $300-1100 \mathrm{~ms}$ indicated that the negativity became more frontally distributed later in the epoch.

Relative CLAUSE VERB AND HEAD NOUN REgion. Visual inspection of the waveforms suggested fairly widespread negativity in response to the head noun of the OR condition (16) compared to the head noun of the SR condition (15), and at some (especially right posterior) electrodes, less consistent negativity in response to the relative clause verb of the OR condition as well (Figure 7). ${ }^{25}$ To compare these results directly

\footnotetext{
${ }^{25}$ SRs and ORs did not differ significantly at W4 (AdvP immediately preceding the RC verb) in any of the time windows of $0-100 \mathrm{~ms}(F(1,21)=0.01$, n.s. $), 100-200 \mathrm{~ms}(F(1,21)=1.74$, n.s. $), 200-300 \mathrm{~ms}(F(1,21)=$ 1.42 , n.s. $), 300-400 \mathrm{~ms}(F(1,21)=1.17$, n.s. $)$, or $400-500 \mathrm{~ms}(F(1,21)=0.01$, n.s. $)$.
} 


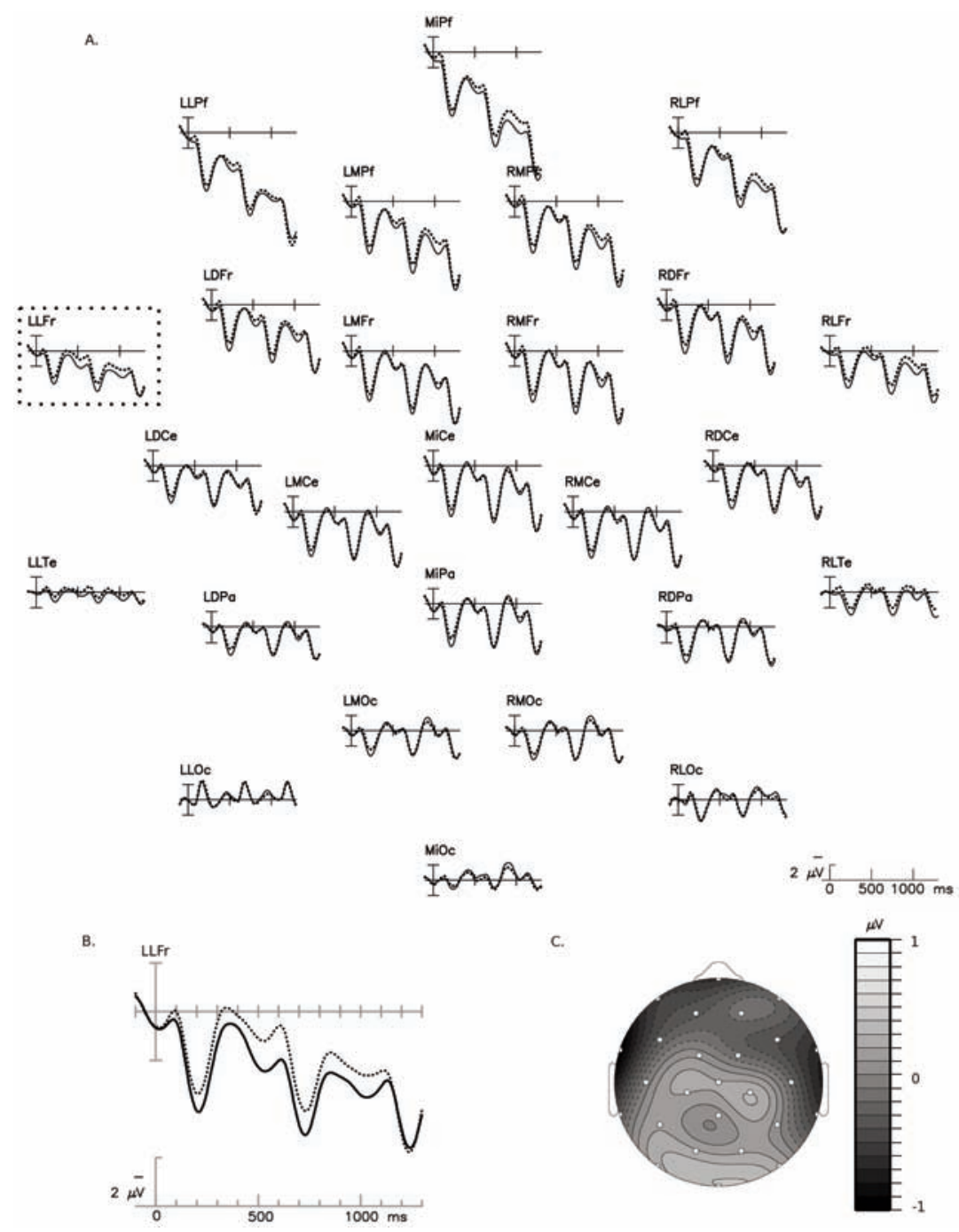

FIGURE 6. A. Grand average ERP waveforms in response to NP-ACC/NOM in subject ('publisher-ACC secretly'; solid line - ) and object relative clauses ('publisher-NOM secretly'; dotted line …) at all twenty-six electrodes sites. B. Grand average ERP waveforms for SRs (-) and ORs ( $\cdots$ ) at the left lateral frontal electrode (the electrode in the dotted square in A). C. Topographic scalp isovoltage map of the mean difference (OR - SR conditions, $300-600 \mathrm{~ms}$ ).

to those of Ueno and Garnsey (2008), an analysis was first conducted on the ERPs to the relative clause verb and the head noun positions together, again in a time window of 300-1100 ms post-stimulus onset of the relative clause verb 'exploit-ADN' (see Table 8 for a summary of the ANOVA results). There was a significant main effect of relative clause type in both the full analysis and the distributional analysis. There were no other significant effects (all $F_{\mathrm{s}}<1.2$ ).

While there was in general more negativity to the relative clause verb and head noun positions in the OR condition, as there had been in Ueno and Garnsey's (2008) study of Japanese relative clauses, the ERP responses to these two sentence positions showed 


\begin{tabular}{|c|c|c|}
\hline \multicolumn{3}{|c|}{ 300-1100 MS POST-ONSET OF 'exploit-ADN' } \\
\hline FULL ANALYSIS & RC type & $F(1,21)=5.22, p<0.0328$ \\
\hline DISTRIBUTIONAL ANALYSIS & $\mathrm{RC}$ type & $F(1,21)=5.72, p<0.0262$ \\
\hline \multicolumn{3}{|c|}{ 300-600 MS POST-ONSET OF 'exploit-ADN' } \\
\hline DISTRIBUTIONAL ANALYSIS & RC type & $F(1,21)=3.37, p<0.08$ \\
\hline LEFT ANTERIOR REGION & RC type & $F(1,21)=4.08, p<0.0563$ \\
\hline LEFT POSTERIOR REGION & RC type & $F(1,21)=0.61$, n.s. \\
\hline RIGHT ANTERIOR REGION & RC type & $F(1,21)=0.06$, n.s. \\
\hline RIGHT POSTERIOR REGION & RC type & $F(1,21)=0.88$, n.s. \\
\hline \multicolumn{3}{|c|}{ 800-1100 MS POST-ONSET OF 'exploit-ADN' } \\
\hline FULL ANALYSIS & RC type & $F(1,21)=8.36, p<0.01$ \\
\hline DISTRIBUTIONAL ANALYSIS & $\mathrm{RC}$ type & $F(1,21)=8.87, p<0.01$ \\
\hline & $\begin{array}{l}\mathrm{RC} \text { type } \times \text { hemisphere } \times \text { laterality } \\
\times \text { anteriority }\end{array}$ & $F(3,63)=2.43, p<0.074$ \\
\hline \multicolumn{3}{|c|}{ 300-600 MS POST-ONSET OF 'senator-GEN' (rebaselined) } \\
\hline FULL ANALYSIS & RC type & $F(1,21)=1.93$, n.s. \\
\hline DISTRIBUTIONAL ANALYSIS & $\mathrm{RC}$ type & $F(1,21)=2.33$, n.s. \\
\hline LEFT ANTERIOR QUADRANT & RC type & $F(1,21)=5.92, p<0.024$ \\
\hline \multicolumn{3}{|c|}{ 300-600 MS POST-ONSET OF 'senator-GEN' (high-pass filtering data without baselining) } \\
\hline FULL ANALYSIS & $\mathrm{RC}$ type & $F(1,21)=5.69, p<0.027$ \\
\hline DISTRIBUTIONAL ANALYSIS & RC type & $F(1,21)=6.5, p<0.019$ \\
\hline
\end{tabular}

TABLE 8. SR vs. OR experimental sentences: relative clause verb and head noun.

different distributions, suggesting that they were nonidentical. As noted previously, the negativity to the relative clause verb appeared to have a right posterior maximum (Fig. 7C), while the negativity to the head noun was widely distributed over the scalp and more pronounced at frontal sites (Fig. 7D). Moreover, over left frontal regions of the scalp, the response to the relative clause verb in the OR condition was in fact positive in polarity (Figs. 7B and 7C).

Thus separate statistical analyses were undertaken of these two apparently separate effects. In a latency window of 300-600 ms post-stimulus onset of the relative clause verb, there was no significant effect in the full analysis but a marginal main effect of relative clause type in the distributional analysis, reflecting overall greater negativity to the relative clause verb in the OR than in the SR condition (Fig. 7C). However, quadrant analyses in the same latency window revealed a marginal main effect of relative clause type over the left anterior region, where the response was actually more positive to the relative clause verb in the OR than in the SR condition. There were no significant effects over other regions of the scalp.

In a latency window of $800-1100$ ms post-stimulus onset of the relative clause verb 'exploit-ADN' (i.e. 300-600 ms post-stimulus onset of the head noun 'senator-GEN' without rebaselining), there were significant main effects of relative clause type in both the full and distributional analyses, as well as a marginal interaction of relative clause type, hemisphere, laterality, and anteriority in the distributional analysis. This marginal fourway interaction was caused by stronger effects at left lateral and right medial electrodes over anterior regions (see Fig. 7D). Other effects were nonsignificant (all $F_{\mathrm{s}}<1$ ).

When ERPs were rebaselined at the onset of the head noun ('senator-GEN') position (Figure 8), however, there were surprisingly no significant effects of relative clause type in a latency window of $300-600 \mathrm{~ms}$, either in the full analysis or in the distributional analysis. There was, however, a significant effect of relative clause type over the left anterior region of the quadrant analysis, and no significant effects in other quadrants (all 


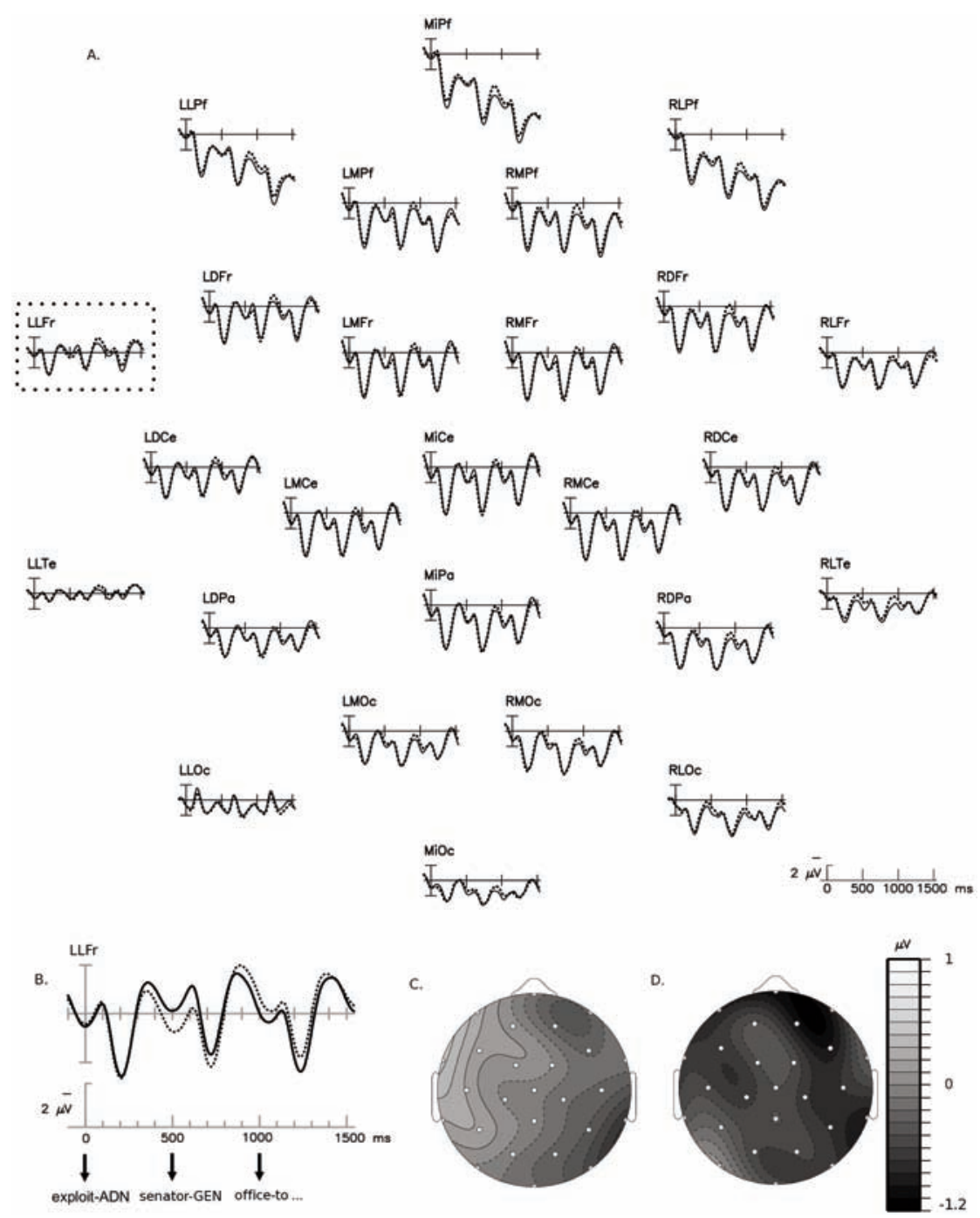

FIGURE 7. A. Grand average ERP waveforms in response to the relative clause verb and head noun positions ('exploit-ADN senator-GEN office-to') in subject (solid line -) and object relative clauses (dotted line $\cdot \cdots \cdot$ ) at all twenty-six electrode sites. B. Grand average ERP waveforms for SR (-) and OR ( $\cdots)$ conditions at the left lateral frontal electrode (the electrode in the dotted square in A). C. Topographic scalp isovoltage map of the mean difference at the relative clause verb (OR - SR conditions, $300-600 \mathrm{~ms})$. D. Topographic scalp isovoltage map of the mean difference at the head noun (OR - SR conditions, $800-1100 \mathrm{~ms}$ post-stimulus onset of the relative clause verb).

$\left.F_{\mathrm{S}}<1.5\right)$. We high-pass filtered our data at $.3 \mathrm{~Hz}$ without baselining from the beginning of the sentence in order to avoid this rebaselining problem at the head noun position. This procedure again yielded significant main effects of relative clause type in both the full and distributional analyses in a latency window of 300-600 ms post-stimulus onset of the head noun, confirming that the response to ORs was more negative than the response to SRs. There were no interactions with relative clause type (all $F_{\mathrm{S}}<1.96$ ). 


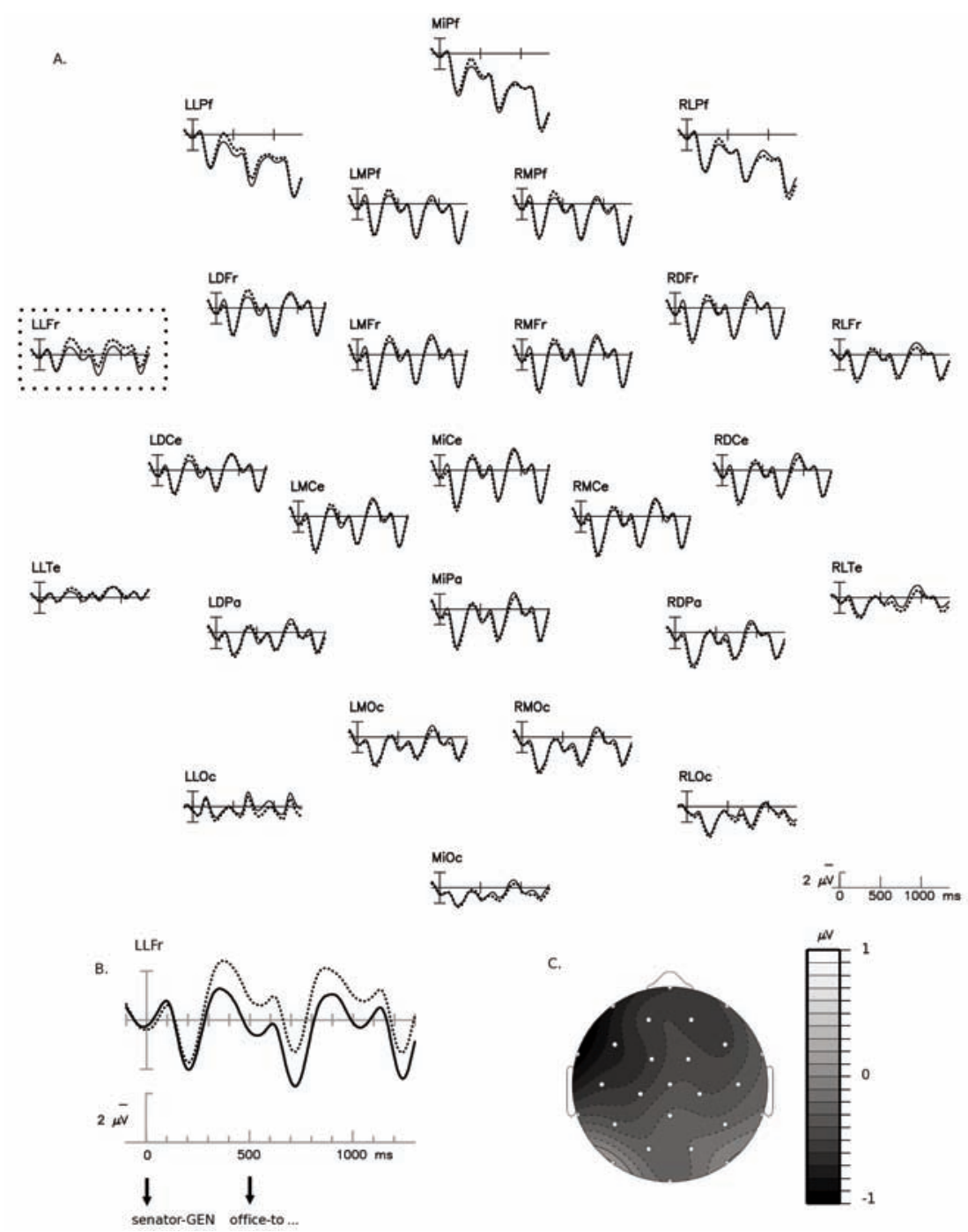

FIGURE 8. A. Grand average ERP waveforms in response to the head noun (and following word/ejel: 'senatorGEN office-to') of subject (solid line - ) and object relative clauses (dotted line $\cdots$...) at all twenty-six electrode sites, with rebaselining. B. Grand average ERP waveforms for SR (-) and OR (‥) conditions at the left lateral frontal electrode (the electrode in the dotted square in A). C. Topographic scalp isovoltage map of the mean difference at the head noun (OR - SR conditions, $300-600 \mathrm{~ms}$ ).

MAIN ClAUSE VERB REgION. There was no effect related to relative clause type in this region. SRs and ORs were not significantly different from each other in any time window.

3. Discussion. The goal of this study was to investigate to what extent the cognitive/neural processes underlying the processing of postnominal relative clauses in languages like English, Dutch, and German resemble those underlying the processing of prenominal relative clauses in head-final languages like Korean. We also wanted to investigate the effect of parametric variation in consistent headedness (Japanese and Korean), case marking (Japanese and Korean), and relative clause marking (Chinese and 
Korean) across the East Asian languages. To address these questions, we also examined the processing of 'baseline' linguistic manipulations, namely sentences that contained phrase structure violations, semantic congruity violations, and 'scrambled' constituents; these data were needed because at the time of the study, no electrophysiological research had previously been done on Korean. These three types of manipulations elicited standard P600, N400, and LAN responses, respectively, in comparison to control sentences with no syntactic violations, semantic violations, or scrambled constituents (i.e. with canonical/unscrambled word order). The responses were similar to previously reported effects in their morphology, latency, and distribution. This suggests that the ERP responses elicited in the processing of Korean sentences are no different from those observed in other languages. ${ }^{26}$

Overall, Korean relative clauses elicited ERP effects quite similar to those elicited by English relatives (King \& Kutas 1995). As in English, in the relative clause region, ORs elicited a negative potential with an anterior maximum when compared to SRs (see discussion in §3.1). At the head noun position, Korean ORs again elicited a negative potential with an anterior maximum, an effect similar to equivalent comparisons in English (King \& Kutas 1995: transient LAN effect) and Japanese relatives (Ueno \& Garnsey 2008: sustained negativity starting from the preceding $\mathrm{RC}$ verb and continuing through the following head noun). By contrast, Korean ORs did not elicit a P600 or variant thereof at sentence positions following the head noun, a finding different from that of Ueno and Garnsey (2008). ${ }^{27}$ This set of results, summarized in Table 9, is discussed below in terms of the effects of major typological features - including pre- vs. postnominal relative clauses and morphological marking — on parsing strategies.

3.1. EFFECTS WITHIN THE RELATIVE CLAUSE REGION PRIOR TO THE EMBEDDED VERB. Within the relative clause region, ORs ('publisher-NOM', 16) elicited a sustained anterior negativity in comparison to SRs ('publisher-ACC', 15). The distribution of slow potential effects has varied across studies (left anterior maximum: Kluender \& Kutas 1993a,b, Kluender \& Münte 1998, Fiebach et al. 2002, Felser et al. 2003; symmetrical anterior maximum: King \& Kutas 1995, Ueno \& Kluender 2003, Phillips et al. 2005; (slightly) right-lateralized anterior-central maximum: Müller et al. 1997, Ueno \& Kluender 2009), though they are in general bilateral and, if lateralized, usually to the left. Thus, it seems that the anterior negativity elicited by ORs at the main argument of the relative clause (W2, 'publisher-NOM'; see Table 9) has an onset latency and a scalp distribution compatible with the anterior negativities reported in previous studies - as well as with the anterior negativity elicited in response to our scrambled sentences (Fig. 4).

However, this effect within the relative clause region is puzzling for several reasons. First, SRs (15) began with an apparently noncanonical sentence-initial NP-ACC, while ORs (16) began with NP-NOM, and thus presented a sentence in seemingly canonical

${ }^{26}$ The one difference we did observe was the lack of any apparent response at the gap position in our scrambled filler sentences (21b), in contrast to reports of transient LAN (Ueno \& Kluender 2003) and P600 effects (Ueno \& Kluender 2003, Hagiwara et al. 2007) elicited by words surrounding gap positions in Japanese scrambled sentences. We have no ready explanation for this apparent crosslinguistic discrepancy at this time.

${ }^{27}$ This lack of late positivity in response to the second element (i.e. the head noun) of a backward gap-filler dependency in a prenominal Korean relative clause contrasted as well with the reported late positivity in response to the second element (i.e. the gap) in a forward filler-gap dependency in Japanese scrambling contexts (Ueno \& Kluender 2003, Hagiwara et al. 2007). As reported above in n. 26, however, we observed no differences in the ERPs to the words preceding (hayngsa-ey 'event-to') or following (chotayhay-ss-ta 'invite-PST-DECL') the gaps in our Korean scrambled sentences (21b). 


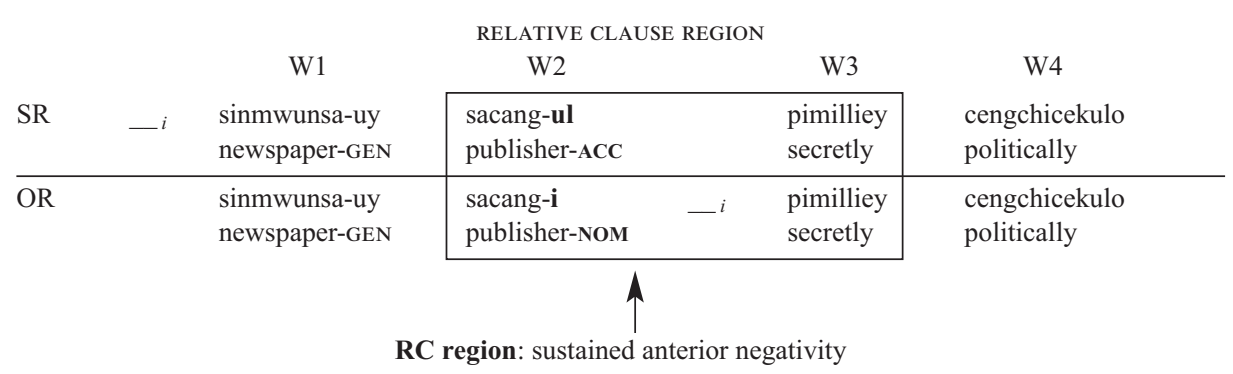

\begin{tabular}{c|c|cccc}
\multicolumn{3}{c}{ RC VERB } & \multicolumn{4}{c}{ MAIN CLAUSE REGION } \\
\cline { 2 - 4 } SR/OR & $\begin{array}{c}\text { W5 } \\
\text { iyongha-n } \\
\text { exploit-REL }\end{array}$ & $\begin{array}{c}\text { W6 } \\
\text { uywon-uy } \\
\text { senator-GEN }\end{array}$ & $\begin{array}{l}\text { W7 } \\
\text { samwusil-ey } \\
\text { office-to }\end{array}$ & $\begin{array}{l}\text { W8 } \\
\text { kkangphay-ka } \\
\text { gang-NOM }\end{array}$ & $\begin{array}{l}\text { W9 } \\
\text { tulichyessta } \\
\text { attacked }\end{array}$ \\
\cline { 2 - 3 } & \multicolumn{4}{c}{$\uparrow$} & \\
Head noun region: transient anterior negativity
\end{tabular}

SR: 'Gangs attacked the office of the senator who secretly took advantage of the publisher of the newspaper for political purposes.'

OR: 'Gangs attacked the office of the senator who the publisher of the newspaper secretly took advantage of for political purposes.'

TABLE 9. Summary of results.

word order starting with the subject. Previous ERP experiments in German and Japanese have shown that scrambled sentences starting with noncanonical objects elicit a (L)AN or a widespread negativity in comparison to sentences starting with canonical subjects (Rösler et al. 1998, Matzke et al. 2002, Schlesewsky et al. 2003, Ueno \& Kluender 2003, Hagiwara et al. 2007, Wolff et al. 2008), and the scrambling condition in our filler sentences replicated these results in Korean (Fig. 4). In light of this, the negativity with an anterior maximum in response to ORs with an initial NP-NOM seems surprising.

One possibility is that the anterior negativity elicited by the relative clause region of our OR experimental sentences (16) is attributable to a strategic processing effect specific to the way in which our experiment was run - but which nonetheless replicates the previous research referred to in the first paragraph of this section. In other words, if this account is correct, it indicates that the strategic processing effect was related to the intrinsic difficulty associated with processing the gap-filler dependency in an object relative clause. Specifically, note that the first two words (ejel) in our experimental SR sentences (15) were always NP-GEN NP-ACC, while the first two words in experimental OR sentences (16) were always NP-GEN NP-NOM (see n. 14 and n. 15). Given the nature of our design, this means that participants saw forty sentences of each of these patterns. But recall from $\S 2.2$ that this study was run concurrently with another experiment in which participants saw another forty object relatives, of which the first two words were also always NP-GEN NP-NOM. The comparison condition in that experiment consisted of forty minimal-pair sentences containing adjunct 'because' clauses that also began with NP-GEN NP-NOM, as they also contained dropped object arguments. Thus overall, nearly one third of the sentences (120/370) that participants saw during experimental sessions contained an object gap-filler sequence of some kind, which moreover always began with NP-GEN NP-NOM (see also n. 17). It therefore appears that whenever participants saw the sequence NP-GEN NP-NOM in our stimulus materials, they had every reason to expect that such a sentence would contain an object gap-filler dependency resolved downstream at the subsequent main clause subject. We believe that the 
negativity elicited in this comparison within the relative clause region was an index of this expectation, since earlier studies have demonstrated that as soon as the brain has reason to believe (usually by virtue of telltale case marking) that there is an object dependency of any type to process, there is a negative voltage deflection relative to conditions that do not contain such a dependency (Kluender \& Münte 1998, Ueno \& Kluender 2009). In some sense, the unintended predictability of the initial case-marking morphology in our backward gap-filler sentences may have performed a processing function similar to that of a filler in a forward filler-gap dependency, namely to signal the presence of an object dependency.

A possible problem for this account of the anterior negativity in response to the relative clause region of OR experimental sentences is that the thirty-five control sentences (21a) for our thirty-five filler scrambled sentences (21b) also began with NP-GEN NPNOM, and one can reasonably wonder why in this case the scrambling condition, which exhibited a different word order (i.e. NP-GEN NP-ACC), would elicit greater anterior negativity instead (see $\$ 2.3$ and Fig. 4). We believe that this may again be due to the fact that the structure of such sentences became apparent across the course of the experimental session, since the scrambling control sentences (21a) always began with 'that NP-GEN NP-NOM' rather than with merely 'NP-GEN NP-NOM', as was the case in object gap-filler dependencies (object relatives). In any case, it is clear that scrambled sentences, which always began unambiguously with 'NP-ACC that NP-GEN NP-NOM', clearly signaled the presence of an object filler-gap dependency with an initial NP-ACC in our stimulus materials, and as such elicited greater anterior negativity than sentences with canonical word order. This is entirely consistent with prior studies in which accusative-marked object NPs have been scrambled in front of nominative-marked subject NPs, both in German (Rösler et al. 1998, Matzke et al. 2002, Schlesewsky et al. 2003) and in Japanese (Ueno \& Kluender 2003, Hagiwara et al. 2007, Wolff et al. 2008). ${ }^{28}$

In summary, Korean object relative clauses elicited a bilateral continuous anterior negativity compared to SRs, remarkably similar to effects seen in English and in response to scrambled sentences in Korean. All three sentence types contain object dependencies, but while English object relative clauses and Korean scrambled sentences contain forward filler-gap dependencies, Korean object relatives contain backward gapfiller dependencies. In addition, Korean object relatives and scrambled sentences differ in their sentence-initial case-marking properties. In spite of all of these surface-level differences in sentence type, case marking, and language family, the brain seems to respond consistently to object dependencies of any type. This appears to be attributable to

\footnotetext{
${ }^{28}$ It is also possible that the negativity to ORs (NP-GEN NP-NOM) in the relative clause region was related to processing difficulty associated with a nominative-marked NP. Nominative-marked NPs in Japanese and Korean have been shown to cause processing difficulty (Kwon 2008a), especially in clauses containing two nominative-marked NPs (Korean: Kim 1999, Kwon 2008a; Japanese: Yamashita 1997, Miyamoto 2002). Subjects often serve as sentential topics (Reinhart 1982, Langacker 1991) that represent old information, and thus tend to be dropped in Korean and Japanese; in Korean, 70\% of subjects are dropped (Kim 2000). When subjects do occur with a nominative marker, which typically encodes new information in Korean (Choi 1997), this may prove to be more difficult to process. Given that the remaining part of the sentence predicates over the subject (cf. Reinhart 1982), successful processing of the subject-predicate relation may reasonably require the subject to be more deeply encoded than other arguments, and this could lead to extra workingmemory demands in ORs (NP-NOM) (for processing difficulty of complex subjects in English, see Kluender 2004). However, an account based on processing costs related to sentence-initial nominative case marking does not explain why there is no ERP effect corresponding to sentence-initial noncanonical word order (i.e. a sentence-initial NP-ACC) in SRs, as was the case in response to our filler scrambled sentences (21b; Fig. 4).
} 
the common working-memory demands of processing object fillers and their associated gaps, irrespective of other typological variables. We return to this point below.

3.2. EFFECTS AT THE EMBEDDED VERB AND THE HEAD NOUN REgION. ORs (16) also elicited significantly greater negativity in comparison to SRs (15) when measurements were taken across the relative clause verb and head noun positions together. When the ERP responses to the relative clause verb and to the head noun were measured separately within this two-word average, that is, without rebaselining, the effect turned out to be stronger at the head noun position but considerably weaker and self-contradictory at the relative clause verb position: there was a marginal main effect of negativity in the distributional analysis but curiously no effect of negativity in the right posterior quadrant, where it appeared maximal (Figs. 7A and 7C), with a marginal effect of positivity in the left anterior quadrant instead. This suggested that the head noun position was driving the overall negative response at the end of the relative clause. Yet when we rebaselined at the head noun position itself (Fig. 8), the effect persisted only in the left anterior quadrant analysis - though this could also have been an artifact of rebaselining, given the marginally significant left anterior positivity in the prior epoch in response to the relative clause verb (see also n. 28). To compensate for this, we high-pass filtered our data starting from the beginning of the sentence without baselining. This again resulted in a significant main effect of greater negativity in response to object relatives at the head noun position. Overall, as this was a planned comparison at a sentence position where we had predicted a LAN effect (9b) and found significant evidence of it in four of the five ways in which we measured it, we conclude that the effect is reliable.

The latency and distribution of this effect are compatible with the transient (left) anterior negativities related to retrieval of fillers at gap positions in ERP studies of forward filler-gap dependencies across languages (English: Kluender \& Kutas 1993a, King \& Kutas 1995; Dutch: Vos et al. 2001; German: Felser et al. 2003; Japanese: Ueno \& Kluender 2003). Thus despite differences in filler-gap ordering, backward gap-filler association in Korean relative clauses elicits transient (L)AN responses that are strikingly similar in nature to those elicited by forward filler-gap association crosslinguistically (see $\$ 3.4$ for a comparison with Ueno and Garnsey's (2008) study of Japanese). ${ }^{29}$

Consider how backward search might operate in a Korean gap-filler dependency, and how this process might result in differential working-memory costs for ORs vs. SRs. Since the beginning of the dependency is not marked by a filler, there is no possibility of filler reactivation. However, the adnominal marker $-(n u) n$ attached to the embedded verb in Korean signals that the current clause serves as a modifier of (cf. 13) or complement to (cf. 12) the following noun. If the relationship is one of modification, at the head noun, the parser is compelled to posit a gap (or an incomplete dependency) and has to retrieve an unfilled argument position from previously parsed material in order to associate that gap with the newly available filler. Such gap-positing and retrieval occurs in both SRs and ORs. But retrieving this unfilled argument position from previously parsed material (or retrieving an incomplete syntactic representation of already parsed

\footnotetext{
${ }^{29}$ Anterior negativities have of course also been elicited in response to phase structure or morphosyntactic violations (Kutas \& Hillyard 1983, Neville et al. 1991, Friederici et al. 1993, Osterhout \& Mobley 1995, Gunter et al. 1997, Coulson et al. 1998, Münte, Heinze, et al. 1998). However, the grammaticality of the SR and OR experimental sentences in the present study as well as their very similar plausibility (2.5 vs. 2.6) and comprehension accuracy scores (70\% vs. $68 \%$ ) suggest that the anterior negativity elicited at the head noun position was more likely related to the working-memory costs associated with processing a filler-gap dependency (Kluender \& Kutas 1993a, King \& Kutas 1995).
} 
material for purposes of gap-filler association) could incur greater working-memory costs in ORs than in SRs, for the following reasons.

Within a subject relative clause, the structural representation of the verb phrase is complete, since both the object and the verb (i.e. 'publisher-ACC exploit-ADN') have already entered the parse when the embedded verb position is encountered. Thus, in this case, semantic interpretation of the verb phrase is readily available, and at the head noun position the parser simply needs to establish the subject-predicate relation between the head noun and the relative clause. At the embedded verb position in an object relative, by contrast, the semantic interpretation of the verb phrase cannot be completed because the object is still missing. Even when the head noun becomes available, its semantic relation with the relative clause is not so straightforward when compared to the subject-predicate relation in SRs. In ORs, the parser's work proceeds in two steps: first, it has to associate the head noun with the missing argument inside the verb phrase. By doing so, it completes the semantic representation of the verb phrase, and only after that can it determine the overall subject-predicate relation within the relative clause by attaching the relative clause subject. This extra step (associating the head noun with the missing argument inside the VP) may impose greater working-memory costs, as indexed by a larger transient LAN to ORs.

3.3. IMPLICATIONS FOR PROCESSING MODELS. Here we discuss the implications of the SR vs. OR processing difference set out in $\S 3.2$ in terms of the theoretical models presented in the introduction. In $\S 1.3$, we noted the failure of linear/temporal-based models of sentence processing to account for the SR processing advantage in Japanese and Korean, and in certain of the available Chinese studies. A related memory-based model is the storage-cost memory account (Gibson 1998, 2000). Storage-cost memory-based theories predict an OR advantage within the relative clause region and an SR advantage at the head noun in head-final languages like Japanese and Korean (Gibson \& Wu 2013). This is based on the temporary ambiguity of Japanese and Korean object relative clauses. Specifically, because an object relative starts with a seemingly canonical NPNOM and is therefore more likely to be interpreted as the main clause of the sentence, a smaller number of syntactic heads are initially required to complete a grammatical structure. Subject relatives, by contrast, start with a noncanonical NP-ACC. Although Korean allows argument-drop, Gibson and $\mathrm{Wu}$ suggest that in a null context, a sentence-initial NP-ACC is likely to trigger a relative clause reading as the initial interpretation. Thus, on this account, SRs are predicted to be more difficult to process within the relative clause region, as more syntactic heads must be predicted to complete a grammatical sequence in SRs than in ORs. In contrast, at the head noun position, ORs are predicted to be more difficult than SRs, as the initial main clause interpretation of ORs will need to be revised.

It is difficult to see how the predictions of this account can be mapped straightforwardly onto the present set of results: object relative sentences elicited larger amplitude negativity over anterior regions of the scalp in response to the relative clause region itself as well as to the head noun. If greater anterior negativity indexes the recruitment of additional verbal working-memory resources, as is commonly assumed, then object relatives were consistently more difficult to process both within the relative clause region and at the head noun position. Gibson and $\mathrm{Wu}$ (2013) instead predict easier processing of object relatives in the relative clause region because the presence of a sentence-initial NP-NOM should encourage the misparse of an OR as the main clause. The pattern of our results is not consistent with this prediction. 
As discussed in $§ 3.1$, it is also possible that participants in our study came to realize that the sentence-initial NP-GEN NP-NOM sequence in our experimental materials reliably introduced an object dependency. Even if participants were able to extract this information strategically, and thus not led to misinterpret an object relative clause as the main clause of the sentence, our results are still incompatible with a storage-cost memory-based account, since it predicts no SR/OR processing asymmetry when there is no structural ambiguity. In particular, Gibson and $\mathrm{Wu}$ (2013) predict that a sentence-initial NP-GEN NP-ACC sequence in a null context should trigger a preferred relative clause reading; strategic processing by our participants may likewise have identified an NP-GEN NP-NOM sequence as a reliable relative clause structure. In this case, both subject and object relative sentences would have been identifiable as such on initial interpretation, and the number of syntactic heads required to complete a grammatical structure would therefore have been the same for SRs and ORs: a relative clause verb, a head noun/main clause subject, and a main verb. This predicts that SRs and ORs should have been equally difficult to process at the head noun position - but again, this was not the pattern of results in our data: ORs elicited greater negativity than SRs at the head noun.

Furthermore, even when structural ambiguity is removed through the addition of preceding context, as in our eye-tracking study (Kwon et al. 2010), the processing disadvantage for object relatives remains. All told, storage-cost memory-based theories do not appear adequate to account for the existing set of data patterns from the processing of Korean relative clauses.

The crucial processing difference between SRs and ORs instead seems to be related to the difficulty of gap-filler association, as discussed at the end of \$3.2: semantic interpretation of the verb phrase is readily available at the relative clause verb position in SRs but not in ORs. Thus interpretation of the head noun is more straightforward in SRs than in ORs ( $\$ 3.1)$. In fact, the processing advantage of SRs coincides with predictions of the accessibility hierarchy (Keenan \& Comrie 1977) and the phrase-structural distance hypothesis (O’Grady 1997; see also §1.3). Object gaps rank lower than subject gaps in the accessibility hierarchy and are more deeply embedded in the phrase structure representation than subject gaps, as shown in 1 and Fig. 1, respectively. Although these two hypotheses are based on different approaches to the study of language (the accessibility hierarchy treats grammatical relations as primitives decoupled from particular syntactic structures, while O'Grady's theory relies on the standard phrase structure representation of grammatical relations adopted in generative grammars), both predict an SR processing advantage not only in VO (e.g. English) but also in OV (e.g. Korean) languages (see Hale 2006 for discussion of linguistically informed parsing models). They further suggest that similar ERP effects in response to filler-gap association in the relative clause and main clause regions in Korean and English could indeed be for similar reasons: in both English and Korean, filler-gap (or gap-filler) association may consume more working-memory resources when the structural representation of a gap is more complex, as it is in ORs. ${ }^{30}$

\footnotetext{
30 The LAN in response to the head noun of ORs is also compatible with incremental and predictive parsing (Yamashita 1994, Sturt \& Crocker 1996, Altmann \& Kamide 1999, Miyamoto 2002, Kamide et al. 2003; but see Pritchett 1991 for a different view). Given the SOV word order of Korean, the noncanonical sentenceinitial NP-ACC in SRs signals a missing subject (i.e. a gap) and a transitive structure, even before the arrival of the verb (cf. Kamide et al. 2003). In ORs, by contrast, there are no comparable cues to the exact structural representation until the embedded verb position. The sentence-initial NP-NOM signals neither a missing argument (i.e. an object gap) nor a transitive structure. It is not until the embedded verb position that the parser
} 
3.4. LANGUAGE UNIVERSALS AND UNIVERSAL PARSING STRATEgIES. In the introduction to this article, we discussed the potential effects of typological variation in word order on sentence processing, mainly focusing on processing requirements involved in pre- vs. postnominal relative clauses in head-initial VO and head-final OV languages. We also discussed major morphological differences across Chinese, Japanese, and Korean: the marking of noun phrases for case in Korean and Japanese and of the right edge of relative clauses in Chinese and Korean. Below we discuss the implications of these crosslinguistic differences for our findings. We first discuss the processing strategies of long-distance dependencies in reference to typological variation in word order (i.e. prevs. postnominal relative clauses) before we compare ERP results from three relative clause studies in East Asian languages with prenominal relative clauses: Korean (present study), Japanese (Ueno \& Garnsey 2008), and Chinese (Yang et al. 2010).

TYPOLOGICAL VARIATION IN WORD ORDER AND ITS EFFECT ON PROCESSING STRATEGIES. Here we compare experimental results from the processing of backward gap-filler dependencies in Korean relative clauses with results from the processing of forward filler-gap dependencies (head-initial relative clauses, wH-questions, and scrambling) in previous studies. In doing so, in our study of backward gap-filler dependencies we find evidence for only two of the three cognitive processes we identified in forward fillergap dependencies (8), and unequivocal, conclusive evidence for only one of these.

By way of analogy to the processing of forward filler-gap dependencies, we suggested that in backward gap-filler dependencies (i) a sustained anterior negativity would be elicited within the relative clause in response to encoding the presence of a gap in working memory, (ii) a transient LAN effect indexing retrieval of a gap to associate with the filler would be elicited at the head noun position, and (iii) late positivity would be elicited at the head noun position, indexing filler-gap integration. Of these predictions, there appeared to be evidence for (i) and (ii) but not (iii): there was greater sustained anterior negativity in response to the relative clause region of ORs, and a transient LAN but no late positivity elicited at the head noun position of ORs.

However, the apparent evidence for (i) may have been an artifact of strategic processing by our participants, as discussed in $\S 3.1$. Since object dependencies with a sentence-initial NP-GEN NP-NOM sequence constituted one third of our experimental stimulus sentences, the early effect of anterior negativity within the relative clause region could have been a mere index of the recognition of this fact. We suspect that this may have been the case, as many previous studies have shown that morphosyntactic cues to the presence of a long-distance object dependency trigger immediate responses of sustained anterior negativity. We are less convinced that this response could have been triggered solely by the presence of a gap with no phonetic, morphosyntactic, or thematic information attached to it, and which moreover could easily have been a mere instance of argument drop. A gap in a backward dependency is simply a silent placeholder in the structural representation: thematic information about the gap comes from

recognizes a missing argument and postulates a transitive structure in ORs, based on the argument structure of the verb. Consequently, gap-filler association at the head noun position could be more difficult in ORs than in SRs because of spillover effects from the preceding embedded verb position, as indexed by the LAN. One problem with this hypothesis, however, is that there was no clear ERP effect associated with recognizing a missing argument and the projection of a transitive structure early within the relative clause in SRs, or at the relative clause verb position in ORs. Although it is possible that such responses in SRs were overshadowed by the response to the relative clause region of object relative sentences, as discussed in $\$ 3.1$, the effect at the relative clause verb position in ORs was quite weak and variable, suggesting that such processes may not demand much in the way of resources at this point in the sentence. 
the relative clause verb, which occurs right before the head noun position, and referential information comes from the head noun itself. This is different from forward fillergap dependencies, in which encoding a filler in working memory as a phonological and/or semantic unit devoid of thematic and grammatical relational information requires dedicated working-memory resources. Since our results with regard to this point were confounded by the possibility of strategic processing, however, final adjudication of this issue will have to await new data.

We were in any case not surprised that there was no index of differential gap-filler integration costs in the form of a late positive response to the head noun: postulation of an unambiguous syntactic gap becomes possible only at the head noun itself both in SRs and ORs, as discussed in $\$ 3.2$.

It thus seems that the only operation truly required in the parse was retrieval of the previously detected missing argument of the verb for association with the filler, as indexed by transient LAN at the head noun position-just as a previously occurring filler is retrieved for association with the gap in a forward filler-gap dependency. Korean ORs with backward gap-filler dependencies elicited a (L)AN effect when compared to SRs at the filler-gap association position (the head noun), just as in comparisons of ORs to SRs at the main clause verb of forward filler-gap dependencies in English relative clauses (King \& Kutas 1995, Müller et al. 1997, Weckerly \& Kutas 1999).

In sum, we have unequivocal electrophysiological evidence for differential processing of backward gap-filler dependencies in Korean subject vs. object relative clauses, indexing apparent working-memory costs related to the complexity of operations involved in retrieving a preceding ambiguous gap and associating it with a filler. This complexity is determined either by the transparency of the predication relation between the head noun and the relative clause ( $\$ 3.2)$ or by the structural complexity of the gap in the relative clause (see $\$ 1.3$ ) - or perhaps both simultaneously. We did not, however, find clear evidence of storage or integration costs related to the gap. This seems perfectly compatible with general notions of incremental parsing as applied to head-final languages, as well as with current cue-based (Lewis \& Vasishth 2005, Lewis et al. 2006) or content-addressable (McElree 2001) models of verbal working memory.

3.5. Morphological difFerences among EAST ASIAN LANGUAGES AND THEIR EFFECTS ON THE PROCESSING OF PRENOMINAL RELATIVE CLAUSES. As shown in $§ 1.2$, Chinese, Japanese, and Korean are in many ways typologically similar. Most relevant to this study is the morphological marking on nouns and verbs. These typological similarities and differences have immediate implications for interpreting the ERP results in Ueno and Garnsey's (2008) study of Japanese RCs, Yang and colleagues' (2010) study of Chinese RCs, and the present study of Korean RCs. In this section, we attempt to reconcile the experimental results across the three studies. Specifically, for the comparison of the Japanese and Korean experimental results, we examine the possibility that the sustained frontal negativity at the embedded verb position reported in Ueno \& Garnsey 2008 corresponds to the sustained frontal negativity within the relative clause region in the present study. We then turn to a discussion of the major difference in the experimental results across studies (i.e. presence or absence of late positivity) and a crosslinguistic difference that is potentially associated (i.e. marking the right edge of the relative clause).

MARKING OF NOUNS AND THE SUSTAINED FRONTAL NEGATIVITY. Recall that in Japanese the greater anterior negativity elicited by ORs started at the embedded verb, that is, BEFORE the head noun (filler) position, and the effect at the head noun position was not statistically reliable, and thus 'seems to be a continuation of that evoked by the previous 
word, the RC verb' (Ueno \& Garnsey 2008:669). There are two possible interpretations of this effect in relation to the findings of the present study. The first is that the effect in Ueno \& Garnsey is independent of the presence of a filler-gap dependency. Although anterior negativity was observed at a different sentence position in the two studies (i.e. Ueno and Garnsey's study: at the relative clause verb [RC NP-ACC/NOM Verb]; present study: at the adverbial phrase [RC NP-ACC/NOM AdvP Verb-ADN]), in both studies the effect was observed immediately following an NP-NOM. This suggests that the effect in Ueno and Garnsey's study could be a reflection of one of the typological similarities between Japanese and Korean, namely case marking of noun phrases, and an index of the costs associated with the processing of overt nominative-marked NPs in these languages (see n. 28).

Another possibility is that the anterior negativity at the embedded verb in Ueno \& Garnsey 2008 is the result of predictive and strategic parsing, similar to the effect within the relative clause in the present study (\$3.1). While SR and OR fragments (NPNOM/ACC Verb) in Japanese can theoretically end at the verb position as a monoclausal sentence, all of the sentences used by Ueno and Garnsey were at least six words long, and the relative clause verb was only the third word in any given sentence. In view of this, Ueno and Garnsey claimed that readers were likely to expect the continuation of the sentence after the relative clause verb. More importantly, based on a norming study in which participants completed a sentence fragment up through the RC verb as a relative clause sentence more than $80 \%$ of the time, Ueno and Garnsey argued that participants were likely to be expecting a relative clause structure at the $\mathrm{RC}$ verb. There was also no ERP response to sentence-initial noncanonical word order (i.e. a sentence-initial NP-ACC) in subject relatives in Ueno and Garnsey's study, just as in the present study. All of this suggests that the anterior negativity elicited by the relative clause region of object relatives in both studies is attributable to strategic/predictive processing. The unintended predictability of the sentence structure based on the case marking of NPs in experimental sentences in both studies may have elicited a processing function similar to that of a forward filler-gap dependency.

Marking OF RELATIVE ClaUSE VERBS AND (SUSTAINED) LATE POSITIVITY. Recall that in Ueno and Garnsey's (2008) study of Japanese relative clauses there was an effect of late positivity at the head noun position of object relatives. ORs in Korean elicited only a LAN, however, just as in English relative clauses, with no late positivity at or after the head noun position. This difference could be due to the lack of morphological marking at the right edge of relative clauses in Japanese. In Japanese, the parser has to construct an embedded clause at the relatively unexpected head noun position, since there is no explicit morphological cue for relative clauses in the language. Although this particular syntactic representation may have been inadvertently signaled by the nature of the stimulus materials, as discussed in the preceding section, this process may still be more difficult when the parser simultaneously has to integrate a more deeply embedded gap (i.e. an object gap) with the head noun (Ueno \& Garnsey 2008). Given that late positivity has been interpreted as an index of syntactic processing difficulty (see $\S 1.4$ ), the greater late positivity elicited by ORs in Ueno and Garnsey's study might thus be attributed to the syntactic integration difficulty presented by head nouns - and in particular the head nouns of object relative clauses - due to the lack of right-edge marking of relative clauses in Japanese. This is different from the processing of Korean relative clauses, in which the adnominal marker at the relative clause verb clearly signals that a noun will follow the current clause, and thus a head noun is expected. 
The one ERP study of Chinese relative clauses (Yang et al. 2010) available in the literature at the time of this writing does not allow a detailed comparison of the effects within the relative clause region with those of the present study due to the complex structure of the experimental sentences (i.e. center-embedded SRs vs. center-embedded garden-pathed ORs). However, Chinese seems overall to pattern more closely with Korean than with Japanese: there is a frontocentral sustained negativity to ORs in comparison to SRs at the head noun position but no subsequent effect of late positivity. This similarity in the ERP responses to the head nouns of Korean and Chinese ORs is likely due to the fact that relative clauses are marked at the right edge in both languages. This provides further evidence that the differences in the ERPs to the head nouns of Korean and Japanese ORs are due to the differences in morphological marking of the relative clause (yes in Korean, no in Japanese).

MiXed Results aCross SEVERAL CHINESE STUdies. One remaining question is why there is so much variation in the experimental results in Chinese. One possibility is that the mixed results across different studies reflect the mixed headedness of Chinese. As discussed in $\S 1.1,98 \%$ of VO languages also have head-initial postnominal relative clauses and Chinese is the sole exception (Dryer 1992). Its root clauses exhibit SVO word order (i.e. head-initial), but its relative clauses are prenominal (i.e. head-final: [RC ... Head Noun). With these two patterns, Chinese ORs follow canonical word order ([RC $\left.\mathrm{SV}_{\text {_ }}\right]$-de $\mathrm{O}$ ); the only difference from a root clause is the presence of the clitic $-d e$ at the right edge of the relative clause. For example, as can be read even off the English glosses, the OR in 24 coincides exactly with the canonical word order in root clauses (SVO), while the SR in 23 does not.

(23) [gōngjīi jìzhě-de] yìyuán attack reporter-DE senator

(24) [yìyuán gōngjī-de] jìzhě senator attack-DE reporter

The availability of the root clause interpretation could positively affect the parsing efficiency of ORs like 24 since readers have had ample exposure to that particular word order. In addition, even when relative clauses are initially misanalyzed as root clauses due to lack of initial relative clause boundary marking in Chinese (Hawkins 1990; $\S 1.1$ ), the processing of object relatives could be facilitated, since the interpretation of the initial misanalysis (i.e. the canonical word order analysis) is identical to that of the revised structure in terms of 'who did what to whom' for Chinese object relatives (cf. Kanno 2007, Yip \& Matthews 2007). Recall that out of sixty-one SVO languages surveyed by Dryer (1992), Chinese was the only one with prenominal/head-final relative clauses. Thus while Hawkins (1990) suggests that languages are shaped in a way that facilitates efficient parsing, and that prenominal/head-final relative clauses are therefore dispreferred crosslinguistically, the processing costs of such structures in Chinese could be mitigated by the fact that object relative and root clauses exhibit the exact same word order, and by the clear morphological marking on the right edge of all Chinese relative clauses.

In sum, the mixed results regarding relative clause asymmetries in the Chinese processing literature may be due to the different relative weightings of several factors. That is, the relative ease of the initial misinterpretation and subsequent reanalysis of ORs could give them a processing advantage in some studies, while the linguistic complexity discussed in $\S 3.3$ could result in the SR processing advantage found in other studies. 
4. Conclusions. This article investigated the brain responses elicited by relative clause constructions in Korean, namely sustained anterior negativity in response to the relative clause region and transient anterior negativity to the head noun position. While the response occurring early in the relative clause may have been induced by strategic processing among the participants in our study, it nonetheless demonstrates that as soon as the parser anticipates an upcoming object dependency, an immediate brain response of sustained negativity is elicited over anterior regions of the scalp. This is consistent with numerous studies in the literature, as well as with our own scrambling results. Within the East Asian languages, the transient response to the head noun position in our data seemed most similar to that elicited by Chinese relative clauses. We suggested that this was because the relative clause not only precedes the head noun but is also morphologically marked at its right edge in Korean and Chinese. Moreover, these results clearly demonstrated similarity in the processing of backward and forward dependencies in relative clauses of typologically distinct languages: compared to equivalent SRs, Korean ORs (i.e. backward gap-filler dependencies) elicited both sustained anterior negativity in the relative clause region and transient anterior negativity at the gap-filler association position (the head noun), just as English ORs (i.e. forward filler-gap dependencies) elicit sustained anterior negativity in the relative clause region and transient anteriority negativity at the filler-gap association position (the main clause verb) when compared to SRs. This offers further support for the universal processing advantage of SRs over ORs in both types of dependencies. This advantage can be interpreted in two different ways, either in terms of the structural complexity of the gap in the relative clause, or in terms of the predication relation that holds between the head noun and the remaining material in the relative clause. Our experimental results overall support processing models based on language universals: the accessibility hierarchy (Keenan \& Comrie 1977) and the phrase-structural distance hypothesis (O’Grady 1997).

APPENDIX: STIMULI USED IN THE EXPERIMENT

(A1) SR: 소아과 의사를 비겁하게 경찰서에 고소한 운전기사의 회사에서 난리가 났다. OR: 소아과 의사가 비겁하게 경찰서에 고소한 운전기사의 회사에서 난리가 났다.

(A2) SR: 부띠끄의 디자이너를 우연히 레스토랑에서 마주친 배우의 소속사에 사람들이 몰렸다. OR: 부띠끄의 디자이너가 우연히 레스토랑에서 마주친 배우의 소속사에 사람들이 몰렸다.

(A3) SR: 마을의 노인을 사심없이 친절하게 도와준 청년의 집에서 경사가 났다. $\mathrm{OR}: \quad$ 마을의 노인이 사심없이 친절하게 도와준 청년의 집에서 경사가 났다.

(A4) SR: 홍보부 팀장을 이유없이 매우 싫어한 실장의 차에 고양이가 숨어들었다. OR: 홍보부 팀장이 이유없이 매우 싫어한 실장의 차에 고양이가 숨어들었다.

(A5) SR: 교회 목사를 언제나 깊이 신뢰한 장로의 건물에서 바자회가 열렸다. $\mathrm{OR}:$ 교회 목사가 언제나 깊이 신뢰한 장로의 건물에서 바자회가 열렸다.

(A6) SR: 도서실의 사서를 오랫동안 깊이 짝사랑한 선생님의 집에서 파티가 열렸다. OR: 도서실의 사서가 오랫동안 깊이 짝사랑한 선생님의 집에서 파티가 열렸다.

(A7) SR: 국회 의장을 공공연히 정면으로 공격한 총장의 집에 기자들이 몰렸다. OR: 국회 의장이 공공연히 정면으로 공격한 총장의 집에 기자들이 몰렸다.

(A8) SR: 부띠끄의 미용사를 우연히도 자주 마주친 여가수의 차에서 폭탄이 터졌다. OR: 부띠끄의 미용사가 우연히도 자주 마주친 여가수의 차에서 폭탄이 터졌다.

(A9) SR: 신문사의 사장을 비밀리에 정치적으로 이용한 의원의 사무실에 깡패가 들이쳤다. OR: 신문사의 사장이 비밀리에 정치적으로 이용한 의원의 사무실에 깡패가 들이쳤다.

(A10) SR: 유치원 교사를 내심 오랫동안 흠모해온 교생의 자전거에 나뭇잎이 떨어졌다. OR: 유치원 교사가 내심 오랫동안 흠모해온 교생의 자전거에 나뭇잎이 떨어졌다.

(A11) SR: 재개발 책임자를 토론차 회의장에서 대면한 시민들의 아파트에서 싸움이 일어났다. OR: 재개발 책임자가 토론차 회의장에서 대면한 시민들의 아파트에서 싸움이 일어났다.

(A12) SR: 프로그램의 작가를 개인적으로 매우 존경한 연출자의 집에서 화재가 발생했다. $\mathrm{OR}:$ 프로그램의 작가가 개인적으로 매우 존경한 연출자의 집에서 화재가 발생했다. 
(A13) SR: 중국집 배달원을 평소에 동생처럼 아낀 미용사의 가게에 화분이 배달됐다.

$\mathrm{OR}$ : 중국집 배달원이 평소에 동생처럼 아낀 미용사의 가께에 화분이 배달됐다.

(A14) SR: 아파트 관리인을 어이없이 술자리에서 폭행한 경비의 지갑에서 돈이 없어졌다.

OR: 아파트 관리인이 어이없이 술자리에서 폭행한 경비의 지갑에서 돈이 없어졌다.

(A15) SR: 고위급 공무원을 오랫동안 비밀리에 지원해온 재경인의 회사에 감사가 있었다.

OR: 고위급 공무원이 오랫동안 비밀리에 지원해온 재경인의 회사에 감사가 있었다.

(A16) SR: 회사 이사를 내심 오랫동안 견제해온 상무의 정원에서 문서가 발견됐다.

$\mathrm{OR}$ : 회사 이사가 내심 오랫동안 견제해온 상무의 정원에서 문서가 발견됐다.

(A17) SR: 프로그램의 진행자를 매우 높게 평가한 여배우의 소속사에 전화가 빗발쳤다.

$\mathrm{OR}$ : 프로그램의 진행자가 매우 높게 평가한 여배우의 소속사에 전화가 빗발쳤다.

(A18) SR: 인기 여가수를 공개적으로 톡톡히 망신준 축구선수의 대학교에서 콘서트가 열렸다.

OR: 인기 여가수가 공개적으로 톡톡히 망신준 축구선수의 대학교에서 콘서트가 열렸다.

(A19) SR: 교회의 목사를 매주 정기적으로 찾아간 장애인의 집으로 선물이 배달됐다.

$\mathrm{OR}$ : 교회의 목사가 매주 정기적으로 찾아간 장애인의 집으로 선물이 배달됐다.

(A20) SR: 미국의 심리학자를 학술적으로 매우 존경한 교수의 대학에서 학회가 열렸다.

OR: 미국의 심리학자가 학술적으로 매우 존경한 교수의 대학에서 학회가 열렸다.

(A21) SR: 이사회 실장을 회의장에서 친절히 안내한 스님의 가방에서 목탁이 없어졌다.

$\mathrm{OR}:$ 이사회 실장이 회의장에서 친절히 안내한 스님의 가방에서 목탁이 없어졌다.

(A22) SR: 연구소의 소장을 은근히 내심 시기한 교수의 연구실에 경보장치가 설치됐다. OR: 연구소의 소장이 은근히 내심 시기한 교수의 연구실에 경보장치가 설치됐다.

(A23) SR: 시민 단체를 공공연하게 적극 후원한 정치인의 자택에 관련자들이 모였다.

OR: 시민 단체가 공공연하게 적극 후원한 정치인의 자택에 관련자들이 모였다.

(A24) SR: 소속사 매니저를 계속해서 공공연히 헐뜯은 배우의 집에서 회의가 열렸다. OR: 소속사 매니저가 계속해서 공공연히 헐뜯은 배우의 집에서 회의가 열렸다.

(A25) SR: 연속극의 작가를 너무나 깊이 신뢰한 감독의 별장에서 행사가 진행됐다.

$\mathrm{OR}:$ 연속극의 작가가 너무나 깊이 신뢰한 감독의 별장에서 행사가 진행됐다.

(A26) SR: 무명의 화가를 부담없이 자주 찾아간 작가의 고향에 신도시가 건설됐다.

$\mathrm{OR}$ : 무명의 화가가 부담없이 자주 찾아간 작가의 고향에 신도시가 건설됐다.

(A27) SR: 유명 소설가를 파티에서 처음 만난 시인의 마을에 벚꽃이 한창이다.

$\mathrm{OR}$ : 유명 소설가가 파티에서 처음 만난 시인의 마을에 벚꽃이 한창이다.

(A28) SR: 홍보부 과장을 속으로 매우 미워한 차장의 책상에 서류가 놓여있다.

OR: 홍보부 과장이 속으로 매우 미워한 차장의 책상에 서류가 놓여있다.

(A29) SR: 행사장 진행자를 거리에서 우연히 마주친 모델의 집으로 꽃다발이 배달됐다.

$\mathrm{OR}$ : 행사장 진행자가 거리에서 우연히 마주친 모델의 집으로 꽃다발이 배달됐다.

(A30) SR: 신인 정치가를 부당하게 낮게 평가한 기자의 신문사에서 회의가 소집됐다.

OR: 신인 정치가가 부당하게 낮게 평가한 기자의 신문사에서 회의가 소집됐다.

(A31) SR: 영화의 스태프들을 여러모로 살뜰히 챙긴 여배우의 정원에 장미꽃이 만발했다. $\mathrm{OR}$ : 영화의 스태프들이 여러모로 살뜰히 챙긴 여배우의 정원에 장미꽃이 만발했다.

(A32) SR: 위원회의 임원을 겨우 간신히 기억해낸 회계사의 회사에서 파티가 있었다.

OR: 위원회의 임원이 겨우 간신히 기억해낸 회계사의 회사에서 파티가 있었다.

(A33) SR: 성가대 지휘자를 후에 다시 만나게된 피아니스트의 자가용에 진흙이 튀었다. $\mathrm{OR}$ : 성가대 지휘자가 후에 다시 만나게된 피아니스트의 자가용에 진흙이 튀었다.

(A34) SR: 구역의 동반장을 몰래 뒤에서 욕한 주부의 부억에 물이 넘쳤다.

OR: 구역의 동반장이 몰래 뒤에서 욕한 주부의 부억에 물이 넘쳤다.

(A35) SR: 항공사의 직원을 이유없이 노골적으로 깔본 일병의 배낭에서 지갑이 떨어졌다. $\mathrm{OR}$ : 항공사의 직원이 이유없이 노골적으로 깔본 일병의 배낭에서 지갑이 떨어졌다.

(A36) SR: 시민 단체를 항상 재정적으로 후원해온 예술가의 집에서 바자회가 열렸다. OR: 시민 단체가 항상 재정적으로 후원해온 예술가의 집에서 바자회가 열렸다.

(A37) SR: 항공사 과장을 작년에 친구로부터 소개받은 여선생의 가방에서 여권이 없어졌다. OR: 항공사 과장이 작년에 친구로부터 소개받은 여선생의 가방에서 여권이 없어졌다.

(A38) SR: 운전학원의 강사를 은근히 몰래 짝사랑한 여직원의 신발에 빗물이 고였다. OR: 운전학원의 강사가 은근히 몰래 짝사랑한 여직원의 신발에 빗물이 고였다.

(A39) SR: 공원의 청소부를 언제나 성심껏 도와준 정원사의 동네에 소나기가 내렸다. $\mathrm{OR}$ : 공원의 청소부가 언제나 성심껏 도와준 정원사의 동네에 소나기가 내렸다.

(A40) SR: 정보 부장을 비밀리에 배후에서 조종하는 외교관의 나라에 기름값이 폭등했다. $\mathrm{OR}$ : 정보 부장이 비밀리에 배후에서 조종하는 외교관의 나라에 기름값이 폭등했다.

(A41) SR: 신문사의 편집장을 끊임없이 집요하게 협박한 총장의 집에서 도둑이 잡혔다. $\mathrm{OR}$ : 신문사의 편집장이 끊임없이 집요하게 협박한 총장의 집에서 도둑이 잡혔다. 
(A42) SR: 인접국의 외교관을 사적으로 특실에서 접견한 장관의 자동차에 폭탄이 장치됐다. OR: 인접국의 외교관이 사적으로 특실에서 접견한 장관의 자동차에 폭탄이 장치됐다

(A43) SR: 마을의 이장을 가까스로 위험에서 구해낸 약사의 가께에서 사람들이 모였다.

OR: 마을의 이장이 가까스로 위험에서 구해낸 약사의 가께에서 사람들이 모였다.

(A44) SR: 영화사의 감독을 오랫동안 비밀리에 위협한 연출자의 가방에서 금품이 발견됐다. OR: 영화사의 감독이 오랫동안 비밀리에 위협한 연출자의 가방에서 금품이 발견됐다.

(A45) SR: 당의 지도부를 대놓고 마구 비방한 의장의 사무실에 기자들이 도착했다.

OR: 당의 지도부가 대놓고 마구 비방한 의장의 사무실에 기자들이 도착했다.

(A46) SR: 대기업의 회장을 어제 간담회에서 소개한 방송인의 마을에서 잔치가 열렸다. OR: 대기업의 회장이 어제 간담회에서 소개한 방송인의 마을에서 잔치가 열렸다.

(A47) SR: 쿠데타의 주동자들을 당일 전국에 지명수배한 수상의 저택에 폭탄이 떨어졌다. OR: 쿠데타의 주동자들이 당일 전국에 지명수배한 수상의 저택에 폭탄이 떨어졌다.

(A48) SR: 대학의 노교수를 항상 건성으로 대접한 총장의 고향에 댐이 건설됐다. $\mathrm{OR}$ : 대학의 노교수가 항상 건성으로 대접한 총장의 고향에 댐이 건설됐다.

(A49) SR: 노조의 대표를 토론차 홀로 만난 이사의 우편함에서 편지가 사라졌다. $\mathrm{OR}:$ 노조의 대표가 토론차 홀로 만난 이사의 우편함에서 편지가 사라졌다.

(A50) SR: 유명 가수를 취중에 심하게 폭행한 배우의 집에서 기자회견이 열렸다. OR: 유명 가수가 취중에 심하게 폭행한 배우의 집에서 기자회견이 열렸다.

(A51) SR: 부대의 사병을 몰래 잔혹하게 죽이려한 소설가의 자가용에 바위가 떨어졌다. $\mathrm{OR}:$ 부대의 사병이 몰래 잔혹하게 죽이려한 소설가의 자가용에 바위가 떨어졌다.

(A52) SR: 학원의 원장을 공식적으로 행사에 초대한 동장의 손가락에서 반지가 없어졌다. OR: 학원의 원장이 공식적으로 행사에 초대한 동장의 손가락에서 반지가 없어졌다.

(A53) SR: 부처의 본부장을 공개적으로 심하게 힐책한 부서장의 사무실에 불이 났다. $\mathrm{OR}$ : 부처의 본부장이 공개적으로 심하게 힐책한 부서장의 사무실에 불이 났다.

(A54) SR: 공장의 직공을 일산으로 친절히 안내한 운전수의 택시에서 지문이 채취됐다. OR: 공장의 직공이 일산으로 친절히 안내한 운전수의 택시에서 지문이 채취됐다.

(A55) SR: 대학의 학자를 언제나 자주 찾아갔던 연구원의 연구실에서 회의가 진행됐다. $\mathrm{OR}$ : 대학의 학자가 언제나 자주 찾아갔던 연구원의 연구실에서 회의가 진행됐다.

(A56) SR: 정당의 사무장을 여러번 우연히 마주친 상무의 별장에서 파티가 열렸다. $\mathrm{OR}$ : 정당의 사무장이 여러번 우연히 마주친 상무의 별장에서 파티가 열렸다.

(A57) SR: 위원회의 임원을 연달아서 심하게 질책한 위원장의 거처에서 총소리가 들렸다. $\mathrm{OR}$ : 위원회의 임원이 연달아서 심하게 질책한 위원장의 거처에서 총소리가 들렸다.

(A58) SR: 우체국의 부장을 강력히 부처에 추천한 경찰관의 숙소에서 화재가 발생했다. OR: 우체국의 부장이 강력히 부처에 추천한 경찰관의 숙소에서 화재가 발생했다.

(A59) SR: 공병대의 병사를 너무나 혹독하게 고문한 하사의 잠자리에서 서적이 발견됐다. $\mathrm{OR}$ : 공병대의 병사가 너무나 혹독하게 고문한 하사의 잠자리에서 서적이 발견됐다.

(A60) SR: 국회 의장을 공개적으로 전폭적으로 지지한 총리의 관저에서 시민들이 데모했다. OR: 국회 의장이 공개적으로 전폭적으로 지지한 총리의 관저에서 시민들이 데모했다.

(A61) SR: 수도원의 수녀를 너무나 정성껏 치료해준 수도사의 봇짐속에 빵이 들어있었다. OR: 수도원의 수녀가 너무나 정성껏 치료해준 수도사의 봇짐속에 빵이 들어있었다.

(A62) SR: 천재적 발명가를 항상 여러모로 도와준 과학자의 실험실에서 생쥐가 죽었다. $\mathrm{OR}$ : 천재적 발명가가 항상 여러모로 도와준 과학자의 실험실에서 생쥐가 죽었다.

(A63) SR: 공원의 정원사를 비겁하게 카드판에서 속이려한 경비의 가슴에 꽃이 달려있었다. OR: 공원의 정원사가 비겁하게 카드판에서 속이려한 경비의 가슴에 꽃이 달려있었다.

(A64) SR: 기업의 사장을 조용히 비밀리에 살해하려한 이사장의 빌라에서 싸움이 있었다. OR: 기업의 사장이 조용히 비밀리에 살해하려한 이사장의 빌라에서 싸움이 있었다.

(A65) SR: 병원의 의사를 수술실로 급하게 호출한 간호사의 사물함에서 마약이 발견됐다. OR: 병원의 의사가 수술실로 급하게 호출한 간호사의 사물함에서 마약이 발견됐다.

(A66) SR: 지역구의 의원을 검찰에 즉시 고발한 시민단체의 사무소에 소포가 배달됐다. OR: 지역구의 의원이 검찰에 즉시 고발한 시민단체의 사무소에 소포가 배달됐다.

(A67) SR: 관리부의 직원을 재빨리 경찰에 신고한 경리의 서랍에서 수표가 발견되었다. $\mathrm{OR}$ : 관리부의 직원이 재빨리 경찰에 신고한 경리의 서랍에서 수표가 발견되었다.

(A68) SR: 회사의 홍보실장을 비밀리에 호텔에서 만난 국장의 서재에서 거래가 이루어졌다. OR: 회사의 홍보실장이 비밀리에 호텔에서 만난 국장의 서재에서 거래가 이루어졌다.

(A69) SR: 아파트의 건설주를 10 년간 비밀리에 협박해온 중개업자의 자택에서 협상이 이루어졌다. $\mathrm{OR}$ : 아파트의 건설주가 10 년간 비밀리에 협박해온 중개업자의 자택에서 협상이 이루어졌다.

(A70) SR: 연구소의 소장을 특별히 공청회에 초대한 정치가의 당사무소에서 여기자가 쓰러졌다. OR: 연구소의 소장이 특별히 공청회에 초대한 정치가의 당사무소에서 여기자가 쓰러졌다.

(A71) SR: 학교의 설립자를 무조건 완전히 내쫓으려했던 이사진의 모임에서 해결책이 논의되었다. $\mathrm{OR}$ : 학교의 설립자가 무조건 완전히 내쫓으려했던 이사진의 모임에서 해결책이 논의되었다 
(A72) SR: 공사의 감독관을 공개적으로 크게 질책한 건축가의 회사에 투서가 배달됐다.

$\mathrm{OR}$ : 공사의 감독관이 공개적으로 크게 질책한 건축가의 회사에 투서가 배달됐다.

(A73) SR: 교향악단의 지휘자를 오페라에 공식적으로 초대한 시의원의 좌석에 오물이 던져졌다.

$\mathrm{OR}$ : 교향악단의 지휘자가 오페라에 공식적으로 초대한 시의원의 좌석에 오물이 던져졌다.

(A74) SR: 극단의 매니저를 너무나 깊이 사모한 무용수의 연습실에서 행사가 치뤄졌다.

OR: 극단의 매니저가 너무나 깊이 사모한 무용수의 연습실에서 행사가 치뤄졌다.

(A75) SR: 공장의 정비사를 오전에 터미널에서 배웅한 미용사의 미용실에서 친구들이 모였다.

OR: 공장의 정비사가 오전에 터미널에서 배웅한 미용사의 미용실에서 친구들이 모였다.

(A76) SR: 콩쿨의 시험관을 우연히 술집에서 알게된 화가의 화실에서 여인이 울고있었다.

$\mathrm{OR}$ : 콩쿨의 시험관이 우연히 술집에서 알게된 화가의 화실에서 여인이 울고있었다.

(A77) SR: 관제탑의 요원을 언제나 진심으로 아껴온 조종사의 호텔에 전보가 배달됐다.

$\mathrm{OR}$ : 관제탑의 요원이 언제나 진심으로 아껴온 조종사의 호텔에 전보가 배달됐다.

(A78) SR: 탄광의 광부를 산속에서 극적으로 발견한 농부의 마을에서 꼬마들이 뛰어놀았다.

OR: 탄광의 광부가 산속에서 극적으로 발견한 농부의 마을에서 꼬마들이 뛰어놀았다.

(A79) SR: 상대팀의 응원단을 무례하게 마구 조롱한 선수들의 훈련장에 아이들이 낙서했다.

OR: 상대팀의 응원단이 무례하게 마구 조롱한 선수들의 훈련장에 아이들이 낙서했다.

(A80) SR: 논밭의 지주를 수차례 직접 방문한 농부들의 텃마루에서 아낙네들이 식사했다.

OR: 논밭의 지주가 수차례 직접 방문한 농부들의 텃마루에서 아낙네들이 식사했다.

\section{REFERENCES}

Altmann, Gerry T., and Yuki KAmide. 1999. Incremental interpretation at verbs: Restricting the domain of subsequent reference. Cognition 73.247-64.

ARNON, InBAL. 2005. Relative clause acquisition in Hebrew: Towards a processing-oriented account. Proceedings of the Boston University Conference on Language Development 29.37-48.

Bader, Markus, and Michael Meng. 1999. Subject-object ambiguities in German embedded clauses: An across-the-board comparison. Journal of Psycholinguistic Research $28.121-43$.

Berwick, RoBert, and Amy WeInBerg. 1983. The role of grammars in models of language use. Cognition 13.1.1-61.

BResnan, JoAn, and Ronald KaPlan. 1982. Introduction: Grammars as mental representations of language. The mental representation of grammatical relations, ed. by Joan Bresnan, xvii-lii. Cambridge, MA: MIT Press.

Caplan, David; Nathaniel Alpert; and Gloria Waters. 1998. Effects of syntactic structure and prepositional number on patterns of regional blood flow. Journal of Cognitive Neuroscience 10.541-52.

Caplan, David; Nathaniel Alpert; and Gloria Waters. 1999. PET studies of syntactic processing with auditory sentence presentation. NeuroImage 9.343-51.

Caplan, David; Nathaniel Alpert; Gloria Waters; and Anthony Olivieri. 2000. Activation of Broca's area by syntactic processing under conditions of concurrent articulation. Human Brain Mapping 9.65-71.

Caplan, David; Sujith Vijayan; Gina Kuperberg; Caroline West; Gloria Waters; Doug Greve; and Anders M. DALE. 2002. Vascular responses to syntactic processing: Event-related fMRI study of relative clauses. Human Brain Mapping 15.26-38.

Caplan, David; Louise Stanczak; and Gloria Waters. 2008. Syntactic and thematic constraint effects on blood oxygenation level dependent signal correlates of comprehension of relative clauses. Journal of Cognitive Neuroscience 20.643-56.

Carreiras, Manuel; Jon Andoni Dunabeitia; Marta Vergara; Irene de la CruzPavia; and ItZiar LaKa. 2010. Subject relative clauses are not universally easier to process: Evidence from Basque. Cognition 115.79-92.

Chen, Baoguo; Ainua Ning; Hongyan Bi; and Susan Dunlap. 2008. Chinese subjectrelative clauses are more difficult to process than the object-relative clauses. Acta Psychologica $129.61-65$.

Chen, Evan; W. Caroline West; Gloria Waters; and David Caplan. 2006. Determinants of bold signal correlates of processing object-extracted relative clauses. Cortex 42.591-604.

Chen, Zhong; Qiang Li; Kue-Lan Kuo; and Shravan Vasishth. 2010. Processing Chinese relative clauses: Evidence for the universal subject preference. Ithaca, NY: Cornell 
University, Dalian: Dalian University of Technology, and Potsdam: University of Potsdam, MS.

Choi, Hye-Won. 1997. Topic and focus in Korean: The information partition by phrase structure and morphology. Japanese/Korean linguistics 6, ed. by Ho-min Sohn and John Haig, 545-61. Stanford, CA: CSLI Publications.

Clemens, Lauren Eby; Jessica Coon; Pedro Mateo Pedro; Adam Morgan; Maria Polinsky; Gabrielle Tandet; and Matt Wagers. 2012. Ergativity and the complexity of extraction: A view from Mayan. Cambridge, MA: MIT, Montreal: McGill University, and Santa Cruz: University of California, Santa Cruz, Ms. Online: http://ling.auf .net/lingbuzz/001630.

Cohen, Laurent, and Jacques Mehler. 1996. Click monitoring revisited: An on-line study of sentence comprehension. Memory \& Cognition 24.94-102.

Constable, R. Todd; Kenneth R. Pugh; Ella Berroya; W. Einar Mencl; Michael Westerveld; Weijia Ni; and Donald Shankweiler. 2004. Sentence complexity and input modality effects in sentence comprehension: An fMRI study. NeuroImage 22.11-21.

Cooke, Ayanna; Edgar B. Zurif; Christian DeVita; David Alsop; Phyllis Koenig; John Detre; James Gee; Maria Pinãngo; Jennifer Balogh; and Murray GrossMAN. 2002. Neural basis for sentence comprehension: Grammatical and short-term memory components. Human Brain Mapping 15.80-94.

Coulson, Seana; Jonathan W. King; and Marta Kutas. 1998. Expect the unexpected: Event-related brain response to morphosyntactic violations. Language and Cognitive Processes 14.21-58.

Dixon, Robert M. W. 1994. Ergativity. Cambridge: Cambridge University Press.

Dryer, MatThew S. 1992. The Greenbergian word order correlations. Language 68.81138.

Felser, Claudia; Harald Clahsen; and Thomas F. Münte. 2003. Storage and integration in the processing of filler-gap dependencies: An ERP study of topicalization and wh-movement in German. Brain and Language 87.345-54.

Fiebach, Christian J.; Matthias Schlesewsky; and Angela D. Friederici. 2002. Separating syntactic memory costs and syntactic integration costs during parsing: The processing of German wh-questions. Journal of Memory and Language 47.250-72.

FoDOR, JANET DEAN. 1978. Parsing strategies and constraints on transformations. Linguistic Inquiry 9.427-73.

Fodor, JANET DEAN. 1983. Phrase structure parsing and the island constraints. Linguistics and Philosophy 6.163-223.

Fodor, Jerry A.; Thomas G. Bever; and Merrill F. Garrett. 1974. The psychology of language: An introduction to psycholinguistics and generative grammar. New York: McGraw-Hill.

Frauenfelder, Ulli; Juan Segui; and Jacques Mehler. 1980. Monitoring around the relative clause. Journal of Verbal Learning and Verbal Behavior 19.328-37.

FraZIER, LYN. 1985. Syntactic complexity. Natural language parsing: Psychological, computational, and theoretical perspectives, ed. by David R. Dowty, Lauri Karttunen, and Arnold M. Zwicky, 129-89. Cambridge: Cambridge University Press.

FraZIER, LYN. 1987. Syntactic processing: Evidence from Dutch. Natural Language and Linguistic Theory 5.519-59.

Frazier, Lyn, and Charles Clifton, JR. 1989. Successive cyclicity in the grammar and the parser. Language and Cognitive Processes 4.93-126.

Friederici, Angela D.; Erdmut Pfeifer; and Anja Hahne. 1993. Event-related brain potentials during natural speech processing: Effects of semantic, morphological and syntactic violations. Cognitive Brain Research 1.183-92.

Friedmann, NAAma, and RAma Novogrodsky. 2004. The acquisition of relative clause comprehension in Hebrew: A study of SLI and normal development. Journal of Child Language 31.661-81.

Gibson, Edward. 1990. Recency preference and garden-path effects. Proceedings of the twelfth annual conference of the Cognitive Science Society, 372-79.

Gibson, Edward. 1998. Linguistic complexity: Locality of syntactic dependencies. Cognition $68.1-76$. 
GIBSON, EDWARD. 2000. The dependency locality theory: A distance-based theory of linguistic complexity. Image, language, brain: Papers from the first Mind Articulation Project symposium, ed. by Alec P. Marantz, Yasushi Miyashita, and Wayne O'Neil, 95-126. Cambridge, MA: MIT Press.

GibSon, EdWARD, and IrIS Wu. 2013. Processing Chinese relative clauses in context. Language and Cognitive Processes 28.125-55.

Gouvea, Ana; Colin Phillips; Nina Kazanina; and David Poeppel. 2010. The linguistic processes underlying the P600. Language and Cognitive Processes 25.149-88.

GREENBERG, JOSEPH H. 1963. Some universals of grammar with particular reference to the order of meaningful elements. Universals of language, ed. by Joseph H. Greenberg, 73-113. Cambridge, MA: MIT Press.

Gunter, Thomas C.; Laurie A. Stowe; and Gijsbertus Mulder. 1997. When syntax meets semantics. Psychophysiology 34.660-76.

Hagiwara, Hiroko; Takahiro Soshi; Masami Ishihara; and Kuniyasu Imanaka. 2007. A topographical study on the event-related potential correlates of scrambled word order in Japanese complex sentences. Journal of Cognitive Neuroscience 19.2.175-93.

Hagoort, Peter; Colin Brown; and Jolanda Groothusen. 1993. The syntactic positive shift (SPS) as an ERP measure of syntactic processing. Language and Cognitive Processes 8.439-83.

Hale, John. 2006. Uncertainty about the rest of the sentence. Cognitive Science 30.609-42.

Hawkins, John A. 1983. Word order universals. New York: Academic Press.

Hawkins, JoHn A. 1990. A parsing theory of word order universals. Linguistic Inquiry 21. 223-61.

Hawkins, John A. 1999. Processing complexity and filler-gap dependencies across grammars. Language 75.244-85.

Hawkins, JoHn A. 2004. Efficiency and complexity in grammars. Oxford: Oxford University Press.

Hewitt, George B. 1979. Abkhaz. Amsterdam: North Holland.

Holmes, Virginia M., and J. Kevin O'Regan. 1981. Eye fixation patterns during the reading of relative clause sentences. Journal of Verbal Learning and Verbal Behavior $20.417-30$.

Hsiao, Franny, and Edward Gibson. 2003. Processing relative clauses in Chinese. Cognition 90.3-27.

Huynh, Huynh, and Leonard S. Feldt. 1976. Estimation of the box correction for degrees of freedom from sample data in randomized block and split-plot designs. Journal of Educational Statistics 1.69-82.

IshizuKa, Tomoko; Kentaro NaKatani; and Edward Gibson. 2003. Relative clause extraction complexity in Japanese. Poster presented at the 16th annual CUNY Conference on Human Sentence Processing, MIT.

Ishizuka, Tomoko; Kentaro Nakatani; and Edward Gibson. 2006. Processing Japanese relative clauses in context. Paper presented at the 19th annual CUNY Conference on Human Sentence Processing, CUNY.

Jha, Amishi P., and Gregory McCARThy. 2000. The influence of memory load upon delayinterval activity in a working-memory task: An event-related functional MRI study. Journal of Cognitive Neuroscience 12.90-105.

Just, Marcel A.; Patricia A. Carpenter; Timothy A. Keller; William F. Eddy; and KeIth R. ThulboRn. 1996. Brain activation modulated by sentence comprehension. Science 274.114-16.

KaAn, Edith; Anthony Harris; Edward Gibson; and Philip Holcomb. 2000. The P600 as an index of syntactic integration difficulty. Language and Cognitive Processes 15.159-201.

Kahraman, Baris; Atsushi Sato; Hajime Ono; and Hiromu Sakai. 2010. Relative clauses processing before the head noun: Evidence for strong forward prediction in Turkish. MIT Working Papers in Linguistics (Proceedings of the 6th Workshop on Altaic Formal Linguistics (WAFL6)) 61.155-70.

Kamide, Yuki; Christoph Scheepers; and Gerry T. M. Altmann. 2003. Integration of syntactic and semantic information in predictive processing: Cross-linguistic evidence from German and English. Journal of Psycholinguistic Research 32.37-55. 
KANNO, KAZUE. 2007. Factors affecting the processing of Japanese relative clauses by L2 learners. Studies in Second Language Acquisition 29.197-218.

Kanno, Kazue, and Michiko NaKamura. 2001. Processing of relative clauses by Japanese native speakers and L2 learners. Journal of the Canadian Association for Japanese Language Education 4.134-48.

KeEnAN, EDWARD L., and Bernard Comrie. 1977. Noun phrase accessibility and universal grammar. Linguistic Inquiry 8.63-99.

KIm, YounG-Joo. 2000. Subject/object drop in the acquisition of Korean: A cross-linguistic comparison. Journal of East Asian Linguistics 9.325-51.

Kim, YoungJIN. 1999. The effects of case marking information on Korean sentence processing. Language and Cognitive Processes 14.687-714.

King, Jonathan, and Marcel Adam Just. 1991. Individual differences in syntactic processing: The role of working memory. Journal of Memory and Language 30.580-602.

King, Jonathan, and Marta Kutas. 1995. Who did what and when? Using word- and clause-level ERPs to monitor working memory usage in reading. Journal of Cognitive Neuroscience 7.376-95.

KLUENDER, Robert. 2004. Are subject islands subject to a processing account? West Coast Conference on Formal Linguistics (WCCFL) 23.475-99.

KLuender, Robert, and MarTa Kutas. 1993a. Bridging the gap: Evidence from ERPs on the processing of unbound dependencies. Journal of Cognitive Neuroscience 5.2.196214.

Kluender, Robert, and Marta Kutas. 1993b. Subjacency as a processing phenomenon. Language and Cognitive Processes 8.573-633.

KLuender, Robert, and Thomas F. MÜNTE. 1998. ERPs to grammatical and ungrammatical wh-questions in German: Subject/object asymmetries. Poster presented at the 11th annual CUNY Conference on Human Sentence Processing, Newark, NJ.

Kutas, Marta, and Steven Hillyard. 1983. Event-related brain potentials to grammatical errors and semantic anomalies. Memory \& Cognition 11.539-50.

Kwon, NAYOUNG. 2008a. A parsing paradox in head final languages: Head-driven vs. incremental parsing. North East Linguistic Society (NELS) 37.43-54.

Kwon, Nayoung. 2008b. Processing of syntactic and anaphoric gap-filler dependencies in Korean: Evidence from self-paced reading time, ERP and eye-tracking experiments. San Diego: University of California, San Diego dissertation.

Kwon, Nayoung; Younhyoung Lee; Peter C. Gordon; Robert Kluender; and Maria POLINSKY. 2010. Cognitive and linguistic factors affecting subject/object asymmetry: An eye-tracking study of prenominal relative clauses in Korean. Language 86.54682.

Kwon, Nayoung; Maria Polinsky; and Robert Kluender. 2006. Subject preference in Korean. West Coast Conference on Formal Linguistics (WCCFL) 25.1-14.

LANGaCKer, Ronald W. 1991. Foundations of cognitive grammar, vol. 2: Descriptive application. Stanford, CA: Stanford University Press.

Lehmann, Christian. 1984. Der Relativsatz. Tübingen: Gunter Narr.

Lewis, Richard L., and Shravan Vasishth. 2005. An activation-based model of sentence processing as skilled memory retrieval. Cognitive Science 29.375-419.

Lewis, Richard L.; Shravan Vasishth; and Julie A. Van Dyke. 2006. Computational principles of working memory in sentence comprehension. Trends in Cognitive Sciences $10.447-54$.

Lin, Chien-Jer Charles, and Thomas G. Bever. 2006. Subject preference in the processing of relative clauses in Chinese. West Coast Conference on Formal Linguistics (WCCFL) 25.254-60.

LiN, Yowyu. 2010. Comprehending Mandarin relative clauses: Ambiguity, locality, and expectation. Urbana-Champaign: University of Illinois, Urbana-Champaign dissertation.

Lin, Yowyu, and Susan M. GaRnSEY. 2007. Plausibility and the resolution of temporary ambiguity in relative clause comprehension in Mandarin. Proceedings of the 20th annual CUNY Conference on Human Sentence Processing.

Mallinson, Graham, and Barry BlaKe. 1981. Language typology: Crosslinguistic studies in syntax. Amsterdam: North Holland.

Matzke, Mike; Heinke Mai; Wido Nager; Jascha Rüsseler; and Thomas Münte. 2002. The costs of freedom: An ERP-study of non-canonical sentences. Clinical Neurophysiology 113.844-52. 
McElree, Brian. 2001. Working memory and focal attention. Journal of Experimental Psychology: Learning, Memory, and Cognition 27.817-35.

McLaughlin, Judith; Lee Osterhout; and Albert Kim. 2004. Neural correlates of second-language word learning: Minimal instruction produces rapid change. Nature Neuroscience 7.703-4.

Mecklinger, Axel; Herbert Schriefers; Karsten Steinhauer; and Angela D. FRIEDERICI. 1995. Processing relative clauses varying on syntactic and semantic dimensions: An analysis with event-related potentials. Memory \& Cognition 23.477-94.

Miller, George A., and NoAm Chomsky. 1963. Finitary models of language users. Handbook of mathematical psychology, vol. 2, ed. by R. Duncan Luce, Robert R. Bush, and Eugene Galanter, 419-92. New York: Wiley.

Miyamoto, Edson T. 2002. Case markers as clause boundary inducers in Japanese. Journal of Psycholinguistic Research 31.307-47.

Miyamoto, Edson T., and Michiko Nakamura. 2003. Subject/object asymmetries in the processing of relative clauses in Japanese. West Coast Conference on Formal Linguistics (WCCFL) 22.342-55.

Müller, Horst M.; Jonathan W. King; and Marta Kutas. 1997. Event-related potentials elicited by spoken relative clauses. Cognitive Brain Research 5.193-203.

Münte, Thomas F.; Hans-Jochen Heinze; and George R. Mangun. 1993. Dissociation of brain activity related to syntactic and semantic aspects of language. Journal of Cognitive Neuroscience 5.335-44.

Münte, Thomas F.; Hans-Jochen Heinze; Mike Matzke; Bernardina M. Wieringa; and SöNKE JoHANNES. 1998. Brain potentials and syntactic violations revisited: No evidence for specificity of the syntactic positive shift. Neuropsychologia 36.217-26.

Münte, Thomas F.; Kolja Schiltz; and Marta Kutas. 1998. When temporal terms belie conceptual order. Nature 395.71-73.

Münte, Thomas F.; O. Schwirtz; Bernadette M. Wieringa; Mike Matzke; and SöNKE JoHANNES. 1997. Elektrophysiologie komplexer Sätze: Ereigniskorrelierte Potentiale auf der Wort- und Satz-Ebene. Zeitschrift für Elektroenzephalographie, Elektromyographie und verwandte Gebiete 28.11-17.

NaKamura, Michiko. 2000. Processing of relative clauses: A psycholinguistic study of adult native speakers of Japanese. University of Hawaii Working Papers in Linguistics 31.59-73.

Neville, Helen; Janet L. Nicol; Andrew Barss; Kenneth I. Forster; and Merrill F. GARRETT. 1991. Syntactically based sentence processing classes: Evidence from eventrelated brain potentials. Journal of Cognitive Neuroscience 3.151-65.

O'Grady, William. 1997. Syntactic development. Chicago: University of Chicago Press.

O'Grady, William. 2011. Relative clauses: Processing and acquisition. The acquisition of relative clauses: Functional and typological perspectives, ed. by Evan Kidd, 13-38. Amsterdam: John Benjamins.

Osterhout, Lee, and Phillip J. Holcomb. 1992. Event-related brain potentials elicited by syntactic anomaly. Journal of Memory and Language 31.785-806.

Osterhout, Lee, and Linda A. Mobley. 1995. Event-related brain potentials elicited by failure to agree. Journal of Memory and Language 34.739-73.

Phillips, Colin; Nina Kazanina; and Shani H. Abada. 2005. ERP effects of the processing of syntactic long-distance dependencies. Cognitive Brain Research 22.40728.

POLINSKY, MARIA. 2011. Reanalysis in adult heritage language: New evidence in support of attrition. Studies in Second Language Acquisition 33.305-28.

Polinsky, Maria; Carlos Gómez Gallo; Peter GrafF; and Ekaterina Kravtchenko. 2012. Subject preference and ergativity. Lingua 122.267-77.

Pritchett, BRAdLEy L. 1991. Head position and parsing ambiguity. Journal of Psycholinguistic Research 20.251-70.

Qiao, Xiaomei; Liyao Shen; and Kenneth Forster. 2012. Relative clause processing in Mandarin: Evidence from the maze task. Language and Cognitive Processes 27.61130 .

Reinhart, Tanya. 1982. Pragmatics and linguistics: An analysis of sentence topics. Bloomington: Indiana University Linguistics Club.

Rösler, Frank; Thomas Pechmann; Judith Streb; Brigitte Röder; and Erwin HenNIGHAUSEN. 1998. Parsing of sentences in a language with varying word order: Word- 
by-word variations of processing demands are revealed by event-related brain potentials. Journal of Memory and Language 38.150-76.

Rösler, Frank; Peter PÜtz; Angela Friederici; and Anja Hahne. 1993. Event-related brain potentials while encountering semantic and syntactic constraint violations. Journal of Cognitive Neuroscience 5.345-62.

Schlesewsky, Matthias; Ina Bornkessel; and Stefan Frisch. 2003. The neurophysiological basis of word order variations in German. Brain and Language 86.116-28.

Schriefers, Herbert; Angela D. Friederici; and Katja Kuhn. 1995. The processing of locally ambiguous relative clauses in German. Journal of Memory and Language 34. 499-520.

Schwartz, Florian. 2007. Processing presupposed content. Journal of Semantics 24.373416.

SHELdon, Amy. 1974. The role of parallel function in the acquisition of relative clauses in English. Journal of Verbal Learning and Verbal Behavior 13.272-81.

Stromswold, Karin; David Caplan; Nathaniel Alpert; and Scott Rauch. 1996. Localization of syntactic comprehension by positron emission tomography. Brain and Language 52.452-73.

Sturt, Patrick, and Matthew W. Crocker. 1996. Monotonic syntactic processing: A cross-linguistic study of attachment and reanalysis. Language and Cognitive Processes 11.449-94.

Traxler, Matthew J.; Robin K. Morris; and Rachel E. Seely. 2002. Processing subject and object relative clauses: Evidence from eye movements. Journal of Memory and Language 47.69-90.

Ueno, Mieko, and Susan M. Garnsey. 2008. An ERP study of the processing of subject and object relative clauses in Japanese. Language and Cognitive Processes 23.646-88.

Ueno, Mieko, and Robert Kluender. 2003. Event-related brain indices of Japanese scrambling. Brain and Language 86.243-71.

Ueno, Mieko, and Robert KLuender. 2009. On the processing of Japanese $w h$-questions: An ERP study. Brain Research 1290.63-90.

Vos, Sandra H.; Thomas C. Gunter; Herman H. J. KolK; and Gijbertus Mulder. 2001. Working memory constraints on syntactic processing: An electrophysiological investigation. Psychophysiology 38.41-63.

WARREN, TESSA, and EDWARD GibSON. 2002. The influence of referential processing on sentence complexity. Cognition 85.79-112.

WeCKERly, Jill, and MarTa Kutas. 1999. An electrophysiological analysis of animacy effects in the processing of object relative sentences. Psychophysiology 36.559-70.

Wolff, Susann; Matthias Schlesewsky; Masako Hirotani; and Ina BornkesselSCHLESEWSKY. 2008. The neural mechanisms of word order processing revisited: Electrophysiological evidence from Japanese. Brain and Language 107.133-57.

Yamashita, Hiroko. 1994. Processing of Japanese and Korean. Columbus: The Ohio State University dissertation.

Yamashita, Hiroko. 1997. The effects of word-order and case marking information on the processing of Japanese. Journal of Psycholinguistic Research 26.163-88.

Yang, Chin Lung; Charles A. Perfetti; and Ying Liu. 2010. Sentence integration processes: An ERP study of Chinese sentence comprehension with relative clauses. Brain and Language 112.85-100.

Yip, Virginia, and Stephen Matthews. 2007. Relative clauses in Cantonese-English bilingual children: Typological challenges and processing motivations. Studies in Second Language Acquisition 29.277-300.

Zaksas, Daniel, and Tatiana Pasternak. 2006. Directional signals in the prefrontal cortex and in area MT during a working memory for visual motion task. Journal of Neuroscience $26.11726-42$.

Kwon

Department of English

School of Humanities and Social Sciences

Konkuk University

Neungdong-ro 120, Gwangjin-gu

Seoul, Korea, 143-701

[nayoungkwon@konkuk.ac.kr]
[Received 3 December 2011; accepted pending revisions 13 August 2012; revision received 13 March 2013; accepted 12 April 2013] 
Kluender

Department of Linguistics, UCSD

[kluender@ling.ucsd.edu]

\section{Kutas}

Department of Cognitive Science, UCSD

[mkutas@ucsd.edu]

\section{Polinsky}

Department of Linguistics, Harvard University [polinsky@fas.harvard.edu] 